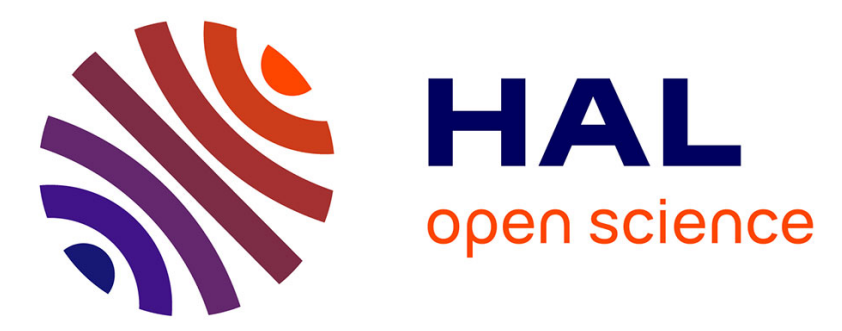

\title{
Offshore Mayotte volcanic plumbing revealed by local passive tomography
}

Océane Foix, Chastity Aiken, Jean-Marie Saurel, Nathalie Feuillet, Stephan Jorry, Emmanuel Rinnert, Isabelle Thinon

\section{To cite this version:}

Océane Foix, Chastity Aiken, Jean-Marie Saurel, Nathalie Feuillet, Stephan Jorry, et al.. Offshore Mayotte volcanic plumbing revealed by local passive tomography. Journal of Volcanology and Geothermal Research, 2021, 420, pp.107395. 10.1016/j.jvolgeores.2021.107395 . insu-03466310

\section{HAL Id: insu-03466310 https://hal-insu.archives-ouvertes.fr/insu-03466310}

Submitted on 2 Mar 2022

HAL is a multi-disciplinary open access archive for the deposit and dissemination of scientific research documents, whether they are published or not. The documents may come from teaching and research institutions in France or abroad, or from public or private research centers.
L'archive ouverte pluridisciplinaire HAL, est destinée au dépôt et à la diffusion de documents scientifiques de niveau recherche, publiés ou non, émanant des établissements d'enseignement et de recherche français ou étrangers, des laboratoires publics ou privés. 


\section{Journal Pre-proof}

Offshore Mayotte volcanic plumbing revealed by local passive tomography

Océane Foix, Chastity Aiken, Jean-Marie Saurel, Nathalie Feuillet, Stephan J. Jorry, Emmanuel Rinnert, Isabelle Thinon, MAYOBS/REVOSIMA Seismology Team

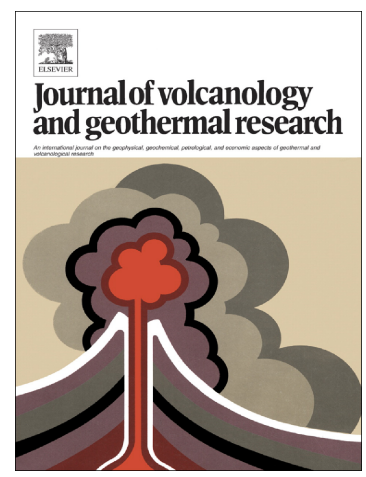

PII: $\quad$ S0377-0273(21)00224-9

DOI: $\quad$ https://doi.org/10.1016/j.jvolgeores.2021.107395

Reference: $\quad$ VOLGEO 107395

To appear in: Journal of Volcanology and Geothermal Research

Received date: $\quad 4$ March 2021

Revised date: $\quad 8$ September 2021

Accepted date: $\quad 11$ September 2021

Please cite this article as: O. Foix, C. Aiken, J.-M. Saurel, et al., Offshore Mayotte volcanic plumbing revealed by local passive tomography, Journal of Volcanology and Geothermal Research (2021), https://doi.org/10.1016/j.jvolgeores.2021.107395

This is a PDF file of an article that has undergone enhancements after acceptance, such as the addition of a cover page and metadata, and formatting for readability, but it is not yet the definitive version of record. This version will undergo additional copyediting, typesetting and review before it is published in its final form, but we are providing this version to give early visibility of the article. Please note that, during the production process, errors may be discovered which could affect the content, and all legal disclaimers that apply to the journal pertain.

(C) 2021 Elsevier B.V. All rights reserved. 


\section{Offshore Mayotte Volcanic Plumbing Revealed by Local Passive Tomography}

\section{Authors List:}

- Océane Foix ${ }^{1}$ (oceane.foix@ifremer.fr)

- Chastity Aiken ${ }^{1}$ (chastity.aiken@ifremer.fr)

- Jean-Marie Saurel ${ }^{2}$ (saurel@ipgp.fr)

- MAYOBS/REVOSIMA Seismology Team (seismo_mayotte@services.cnrs.fr)

- Nathalie Feuillet ${ }^{2}$ (feuillet@ipgp.fr)

- Stephan J. Jorry ${ }^{1}$ (stephan.jorry@ifremer.fr)

- Emmanuel Rinnert ${ }^{1}$ (emmanuel.rinnert@ifremer.fr)

- Isabelle Thinon ${ }^{3}$ (i.thinon@brgm.fr)

${ }^{1}$ IFREMER, Unité Géosciences Marines, Technopole La Poiı te a ו Diable, 29280 Plouzané, France

${ }^{2}$ Université de Paris, Institut de physique du globe de Pari. CJ IRS, F-75005 Paris, France

${ }^{3}$ BRGM-French geological survey, DGR/GBS, F-45066 Trléans, France

\section{Corresponding author:}

Océane Foix : oceane.foix@ ifremer.fr (previous r mail address)

foixoceane@ hotmail.fr (permaner. ${ }^{+}-r$ rail address)

Ifremer - Centre de Bretagne

Géosciences Marines, Lab rat ire Aléas et Dynamique Sédimentaire

1625 Route de Sainte Anne

29280 Plouzané France

\section{Abstract.}

A new submarine volcano has been discovered offshore Mayotte, a part of the Comoros volcanic archipelago located between Africa and Madagascar. The edifice arose from the sea- 
floor following a seismo-volcanic crisis that started in May 2018. This seismo-volcanic activity highlights very deep magma reservoirs and dykes in the East Mayotte volcanic system. Since the crisis, the region has experienced $>2,000$ earthquakes with magnitude $\geq 3.5$ and activity continues today (August 17, 2021). The earthquakes are unusually deep and distributed into two swarms: one 5-15 km east of Petite-Terre at 25-55 km depth and a second 25 $\mathrm{km}$ away at 30-50 km depth. Significant subsidence of Mayotte to the East has been assigned to the drainage of a deep magma chamber, inferred to be located $30 \mathrm{~km}$ from the coast. However, at present, the earthquake locations and geodetic observatio.s have not been sufficient to image entirely the structure of the volcanic plumbing ,ys $:$ m. In this study, we construct $\mathrm{Vp}, \mathrm{Vs}, \mathrm{dVp}, \mathrm{dVs}$ and $\mathrm{Vp} / \mathrm{Vs}$ 3D velocity models to asst:s the deeper structure of the young volcano plumbing system, offshore and East of Maysth Using > 3,000 earthquakes from an ongoing monitoring effort, and a $1 \mathrm{D}$ velocity $\mathrm{n}_{\mathrm{V}}$ te' determined onboard, we jointly inverted for velocity structures, earthquake locat. nn , origin times, and station corrections using LOTOS software. The calculated 3D velou ${ }^{t y}$ models highlight a complex volcanic system down to $40 \mathrm{~km}$ depth. Specifically, we imag “ interpreted reservoirs, more or less consolidated/old. The main reservoir is located a abuut $30 \mathrm{~km}$ depth and deeper, making it one of the deepest magmatic chamber imaged. The reservoirs are connected by several old crystallized conduits, whose existence could i av been influenced by the presence of an old fracture zone, globally oriented $\mathrm{N} 130^{\circ}$, due to a regional strike-slip motion of the lithosphere. Moreover, gassaturated rock may be present below the currently degassing Horse Shoe structure. We were unable to image connections between the new volcanic edifice and reservoirs or conduits due to a lack of resolution in that part of the study area.

Keywords: Earthquake tomography, active volcano, volcano seismology, magma chamber, 
Comoros archipelago, Indian Ocean. 


\section{Introduction}

Deep volcanic systems are not well understood, and seismic imaging them are rare. Some earthquake tomography studies of deep volcanic systems have been conducted along subduction zones, such as the Toba volcano (Koulakov et al., 2009a) and Kamchatka volcanic complex (Koulakov et al., 2020a). Those studies highlighted ascending magma resulting from the dehydration of the subducting plate. It is known that subduction zone volcanic arcs involve crust and mantle multilevel magma-reservoirs (i.e., Dobretsov et al., 2012 and above referees). However, we do not know deep volcanic feeding svicter's in other geological contexts, such as that of Mayotte. Here, we investigate Mayc tut volcanic system to understand what influences deep volcanic system structure and behavir.

Mayotte is part of the Comoros volcanic arrhir lago (CVA) located between South Africa and Madagascar, in the Mozambique C: an .el (figure 1, A). The on-going seismovolcanic crisis highlights a complex syst. $m$ ' Jecause we do not know its deep crustal structure. Since May 2018, seismicity has contiı. ed to occur offshore Mayotte, where a new volcanic edifice (NVE) has been discoverer at $5 r \mathrm{~km}$ to the East of Petite-Terre. The edifice is located at the eastern part of a $\mathrm{N} 130^{\circ}$ lignınent of volcanic edifices that we label the volcanic ridge (figure 1) (Feuillet et al., 20^^• '021). Early-recorded earthquake sequences (2018-2019) and petrology have provide' sunle understanding of the link between a deep magma chamber and the new volcano (Lemoine et al., 2020; Cesca et al., 2020; Laurent et al., 2020; Berthod et al., 2021). However, we still lack a deeper understanding of the overall volcanic plumbing structure of East Mayotte volcanic ridge (EMVR) in terms of its past and present-day activity.

The Mozambique Channel tectonic regime is influenced by an East-Northeast WestSouthwest offshore extension of the East African Rift System (e.g., Deville et al., 2018 and its references). Magmatic activity in the CVA appeared first in Mayotte, 20 Myr ago, followed by Anjouan, Mohéli, and Grande Comore 10-11 Myr ago (Nougier et al., 1986; Michon, 
2016). The more recent volcanic activity is dated in Grande Comore (Karthala) at $0.13 \pm 0.02$ Myr to present. The CVA origin is still debated. Emerick and Duncan (1982) proposed the presence of a hot spot, but the inference does not match with velocity models of plate motion and structural features of the region (Famin et al., 2020). It could also be influenced by lithospheric fractures (Nouguier et al., 1986) or result from a combination of both processes (Debeuf, 2004; Michon 2016). A more recent work, based on the current seismo-volcanic crisis, interprets the region as undergoing lithospheric-scale rifting (Feuillet et al., 2021). Several NW-SE ridges and rifts are organized in échelon to transfer $t_{1}{ }^{2}$ deformation from EastAfrican rift (Feuillet et al., 2021). Famin et al. (2020) inte' $\mu^{+}$tne region as a plate limit with dextral motion while Stamps et al. (2020) consider the CVA as the northern extent of a diffuse transtensional zone accommodating the extens: ol hetween the Somalian and Rovuma plates.

Fig.1. Mayotte volcano-seismic settings. A: C mo' ss archipelago and Mayotte locations marked by the black rectangle. B: Close-up on the Comoros arch ${ }_{1}{ }^{\circ}{ }^{\circ}$ lago and Mayotte Islands. Red triangles are known active volcanoes. C: Close-up on Mayotte Grande-Te re d d $d$ Petite-Terre islands area. Black triangles represent land and offshore seismic stations available bet" een rebruary and November 2019. Circles illustrate earthquakes distribution recorded by seismic stations, win' size proportional to the magnitude and color dependent on depth. Grey patches indicate volcanic coner an . idges with names determined by Feuillet et al. (2021). PSC: Proximal Seismic Cluster. DSC: Dista' Stivnic cluster. NVE: New volcanic edifice.[COLOR NEEDED]

Locally, explosive volcanic eruptions on Grande-Terre and Petite-Terre (Mayotte islands) have been describe. The latest dated tephra on land occurred between 4,000 and 7,000 years, but its origin was not determined (Zinke et al., 2003a; 2003b). At sea, recent activity is evidenced by the presence of several cones on the insular slope (Audru et al., 2006; Famin et al., 2020; Tzevahirtzian et al., 2021; Feuillet et al., 2021). According to the lithospheric-scale rifting of the region, these cones are distributed along a W-NW / E-SE volcanic ridge $\left(\mathrm{N} 130^{\circ}\right)$ where the NVE (820 m high and $\sim 5 \mathrm{~km}$ wide) has been discovered (Feuillet et al., 2021). 
Feuillet al al. (2021) highlights the Horse Shoe (HS) degassing structure, with a $3.5 \mathrm{~km}$ wide cone, and the Crown, with a $4 \mathrm{~km}$ wide circular structure composed of 100-150 m high volcanic edifices, suggesting post-caldera domes (figure 1, C). A $10 \mathrm{~km}$ wide flat depression seems to surround the Crown. In addition, the nature of the lithosphere offshore Mayotte to the East is still unknown; its oceanic or continental nature is still debated. Beneath Mayotte island, the depth of the Moho has been estimated to be at $18 \mathrm{~km}$ depth in the region based on a receiver function study (Dofal et al., 2018).

For several years, the Mayotte region has been considareci as a moderate seismically active area, having produced several M5 events and one ev nt with a maximum magnitude evaluated at 6.1 MLv (Bertil et al, 2018). Since May $)_{1}$ ? the Mayotte inhabitants have felt hundreds of earthquakes. Most are small in magni uu but several moderate-sized events have occurred (monthly report of REVOSIM 1 . r.tps://www.ipgp.fr/fr/revosima/actualitesreseau). On 15 May 2018, a M5.9 eveni ncr arred and due to the weakening of structures and previous minor damages from previou earthquakes, induced damages to buildings (Masson et al., 2018). The present-day sej mo $\mathrm{v}$ slcanic crisis has been accompanied by a significant subsidence of Mayotte Island between 9 and $17 \mathrm{~cm}$ (Lemoine et al., 2020; Cesca et al., 2020; Feuillet et al., 2021). Th:s subsidence has been assigned to the drainage of a magma chamber. A number oı very low frequency (VLF, 15s oscillation period) events have been recorded and the largest one, recorded worldwide, occurred on 11 November 2018. Its occurrence has been attributed to fluid movement within the volcanic system (Cesca et al., 2020; Laurent et al., 2020; Feuillet et al., 2021). Since 2019, seismicity has been concentrated primarily near Petite-Terre (PSC: Proximal Seismic Cluster, figure 1), at about 5 to $15 \mathrm{~km}$ from the coast, and at a depth ranging from 25 to $55 \mathrm{~km}$ from the seafloor, below the Moho, with an apparent donut-shaped ring in map view (Jacques et al., 2019; Lavayssière et al., 2020; Feuillet et al., 2021). This activity represents $90 \%$ of the present-day located events (Saurel et 
al., resubmitted). A secondary seismic cluster of earthquakes (DSC: Distal Seismic Cluster, figure 1) is located $25 \mathrm{~km}$ East from Petite-Terre, between 30 to $50 \mathrm{~km}$ depth, and shows no clear evidence of a connection to the PSC. From the DSC, a thin N140 seismic region extends toward the NVE with depth appearing to diminish approaching the edifice (Saurel et al., resubmitted).

Thanks to the many oceanographic deployments (MAYOBS series, Feuillet et al., 2019), more than 3,000 earthquakes have been recorded by the land-based network and relocated with the multiple OBS deployed along the EMVR (figrre :). These $~ 3,000$ manually relocated earthquakes provide a unique opportunity to $\mathrm{pr}$, un 'e a local 3D seismic image of the deep crustal structure beneath the EMVR in the conte. ${ }^{+}$of present-day earthquake activity (Saurel et al., resubmitted). From the 3D velocity mode, we produced in this study, we aim to answer the following questions: Are there one o. se /eral magmatic reservoirs involved in the East Mayotte volcanic system? Where a $\cdot t^{\prime}$ 'ey? Is there an influence of the regional tectonic regime on the volcanic plumbing syste $\urcorner$ ? Can we image gas related to the volcanic activity? Does the East Mayotte volcanic cvs, ar.1 have an old volcanic plumbing history, or is it a young, neoformed system?

Using well-resolved ar hquake locations, hand-picked earthquake phases, and a 1D velocity model in LOT'S (Local Tomography Software - Koulakov, 2009), we present in this work the first local passive earthquake tomography images of the volcanic plumbing system of East Mayotte, offshore. In the following sections, we detail the local passive tomographic inversion methods we employ to image the East Mayotte volcanic system (EMVS) (Section 2), and our tomographic imaging results along the EMVR (Section 3). We discuss the imaging in the context of known geology and seismicity as well as known topography from bathymetric mapping conducted during the many oceanographic campaigns since 2019 (Section 4). This work provides a detailed structure of the EMVS and provides a deeper understanding 
of the larger-scale lithospheric processes involved in the region, from past to present.

\section{Passive Local Tomography Inversion}

\subsection{Networks and input data}

MAYOBS is a series of monitoring surveys dedicated to follow the evolution of the seismo-volcanic crisis affecting Mayotte since May 2018. The long-term project includes several successive OBS recoveries and deployments from February 2019 to the present day (Feuillet et al., 2019). Only a local seismic stations network is $u_{\triangleright}>d$ for this study, and it is composed of 70 onshore and offshore stations (grey triang' ${ }^{\prime}$ is t1gure 1 and tables S1 and S2): (1) 10-land seismometers were progressively set up on r tite-Terre and Grande-Terre (table S2). One of them failed after a few days (RCBF0) ?nu recorded only 2 phases. (2) Between February and November 2019, between 6 and 1: O 3S were deployed and recovered every 3 to 4 months. A total of 12 INSU-IPGP hr t period OBS (Institut National des Sciences de l'Univers - Institut de Physique du Gı he de Paris) and 48 IFREMER micrOBS or LotOBS (Institut Français de Recherche prir 'Fxploitation de la Mer) were used (table S1). One instrument could not be recover 1 (li $3 \mathrm{~B}$ ). At present, more than 4,000 earthquakes have been manually picked and locatea ' $v$ the MAYOBS/REVOSIMA (Réseau de Surveillance Volcanologique et Sismologiq $\cdot$ ue Mayotte) seismology team. More details about instruments and earthquakes locations may be found in Saurel et al. (resubmitted) or on the REVOSIMA bulletin webpage (https://www.ipgp.fr/fr/revosima/reseau-de-surveillance-volcanologiquesismologique-de-mayotte). Due to the need to monitor the crisis and the lack of time or technical solution (as non-communication of the instrument), some of the instruments were not relocated. Their deviation due to the water current was estimated to be $\sim 300 \mathrm{~m}$. To estimate the effect of this uncertainty on the tomographic inversion, we performed two tests, presented and discussed in detail in Section 2.3. 
We extracted a total of 3,843 events that occurred between February and November 2019 from the MAYOBS relocated earthquake catalog, defined as the "initial catalog". The magnitude of completion is about 2.25 , and the azimuthal gap mean is equal to $98^{\circ}$. The $\mathrm{P}$ and S mean number of phases are 12 and 10, respectively. The mean latitude, longitude, and depth errors are respectively equal to $1.41,1.04$, and $1.92 \mathrm{~km}$, with maximum errors equal to 36.32 , 53.2, and $67.5 \mathrm{~km}$ for the most poorly located event (figure S3). We selected a subset of the initial catalog based on quality criterion so that only the well-constrained events are used for the tomographic inversion: longitude, latitude, and depth errors $<; \mathrm{km}$ and a minimum of $5 \mathrm{P}$ and $3 \mathrm{~S}$ phases recorded per station. We allowed a maxi ${ }^{\prime} \mathrm{u}_{\mathbf{L}^{\prime}}{ }^{\mathrm{d}}$ distance to the nearest station equal or less than $30 \mathrm{~km}$. These selected events have hec labelled as the "filtered catalog",

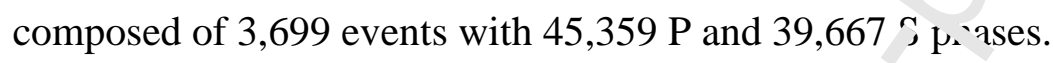

\subsection{Inversion Method and Parameters}

To calculate the 3D seismic vel rit, variations in the Mayotte region, we used LOTOS (Koulakov, 2009). LOTOS jointly inverts for P and S velocity structures, source coordinates, origin times, and station corre to ons through the LSQR method (Paige \& Saunders, 1982). First, the algorithm opt nizes an input 1D velocity model, through 2-4 iterations, and calculates new source locatı. $n$ the model. The algorithm may generate preliminary source locations, if they do no exist. The source locations in 1D are based on a goal function (GF), reflecting the probability of a source to be located at a current point (Koulakov \& Sobolev, 2006). The ray travel times are corrected for station elevations. The GF probability is performed by a grid search method. Second, the optimized 1D velocity model and source locations are then used as initial conditions for a 3D velocity inversion. Sources are relocated with a 3D ray tracing (or bending) method based on the Fermat principle of travel time minimization. The preferred locations are chosen using the GF and a gradient method (Koulakov et al., 2006). 
LOTOS 3D inversion is performed through 3-5 iterations, on four grids with azimuthal orientations of $0,22,45$ and 66 degrees to avoid artifacts related to node distribution (figures S4 and S5). This orientation is given from the center of the model $(45.44,-12.8)$ where each node will undergo a clockwise rotation in latitude and longitude coordinates. Each grid is based on a mesh of nodes fixed in a volume on vertical lines. A uniform spacing distribution is used in map view. On vertical lines, nodes are distributed according to the ray occurrence, such that if there is no ray, then there is no node (figures 2 and S6). Nodes will then be mostly near stations but also at any depth and distance between the source and receiver where the ray travels. Between nodes, velocity values are linearl, $a_{1}$ - broximated. The output model, at each iteration, is the average differential of velocitv $\left(\mathrm{c}^{\mathrm{V}} \mathrm{V}\right)$ between the optimized input $1 \mathrm{D}$ velocity model and the 3D output. The chosen invers' on narameters are described in table 1.

The LOTOS inversion is performed $t^{\prime} \mathrm{rr}_{1} \mathrm{f}^{\mathrm{g}_{1}}$ the LSQR method (Paige \& Saunders, 1982). This method is used in $1 \mathrm{D}$ for th in ersion of the sparse matrix composed of the free parameters (weights in table 1) and in $\mathrm{n}$ ? for the inversion of the first derivative matrix (Koulakov, 2009). In other words, LSCR $\mathrm{i}$ ar ations are specifically related to the minimization between the starting model and $t^{\mathrm{t}} \cdot$, firal model. It is one step of the inversion that is performed within the upper 3-5 iteratio s sf the overall inversion. The larger the value, the sharper the solution is. We chose a hryil value to ensure the convergence of the process (LSQR ite= 80). Weight on P and S velocity models are needed for the inversion process (Vp wgt / Vs wgt). We used equal phase weights in this study. In the joint inversion process, the velocity and hypocenter partial derivative matrix is supplemented by two sub-matrices that influence the velocity perturbations: a smoothing and a regularization matrix. Increasing the weight on smoothing ( $\mathrm{P}$ smth / S smth), induces a decreasing effect on the anomaly differences in neighboring nodes. From the regularization parameter, increasing its weight (P reg / S reg) reduces the inverted Vp and Vs anomaly amplitudes. Hypocentral shift (Hor wgt / Ver wgt) 
and origin time (Time wgt) weights are also required. These parameters relatively control hypocentral and velocity perturbations. We choose values based on Koulakov (2009). Finally, the software allows for station corrections (P st. wgt / S st. wgt). As our study aims to map travel time variation, we kept a very small weight on this value. In the end, we tested inversion parameters one by one by evaluating their effect on checkerboard and RMS time residuals. The parameter value that gave the best solution regarding checkerboard and RMS time residuals was chosen before running tests with another inversion parameter. In total, we performed 92 model tests and examined them to determine our optima. model parameters.

For our analysis, we use the velocity model develo sei during the MAYOBS1 oceano-

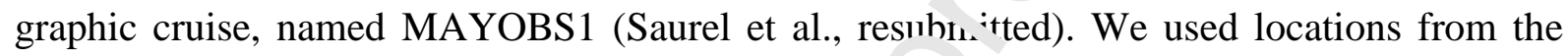
filtered catalog, and seismic station locations. Our F a.t S velocity models are respectively composed of $\sim 16,800$ and $\sim 16,600$ nodes ove $\mathrm{x} .110 \times 90 \times 70 \mathrm{~km}^{3}$ (x, y, z) velocity grid volume with $2 \mathrm{~km}$ of node spacing in $\mathrm{k}$ ri ontal (table 1 and figure 2). We calculated the P

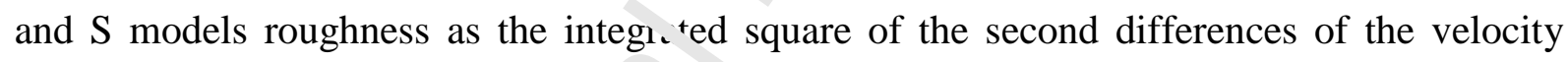
model in 3D (Lees \& Crosson, 1089; 7alt \& Barton, 1998). RMS time residuals and roughness per iteration give us an or imai solution after three iterations (figure 3), where the RMS was not significantly decreas: $n$, and roughness continued to increase. After three iterations in the 3D inversion, the $\mathrm{r}$ anu $\mathrm{S}$ residuals average has been reduced from $0.17 \mathrm{~s}$ and $0.27 \mathrm{~s}$ to $0.12 \mathrm{~s}$ and $0.17 \mathrm{~s}$ (29.41\% and $37.03 \%$ of reduction). The mean earthquake locations uncertainty for this iteration is $3.17 \mathrm{~km}$. 


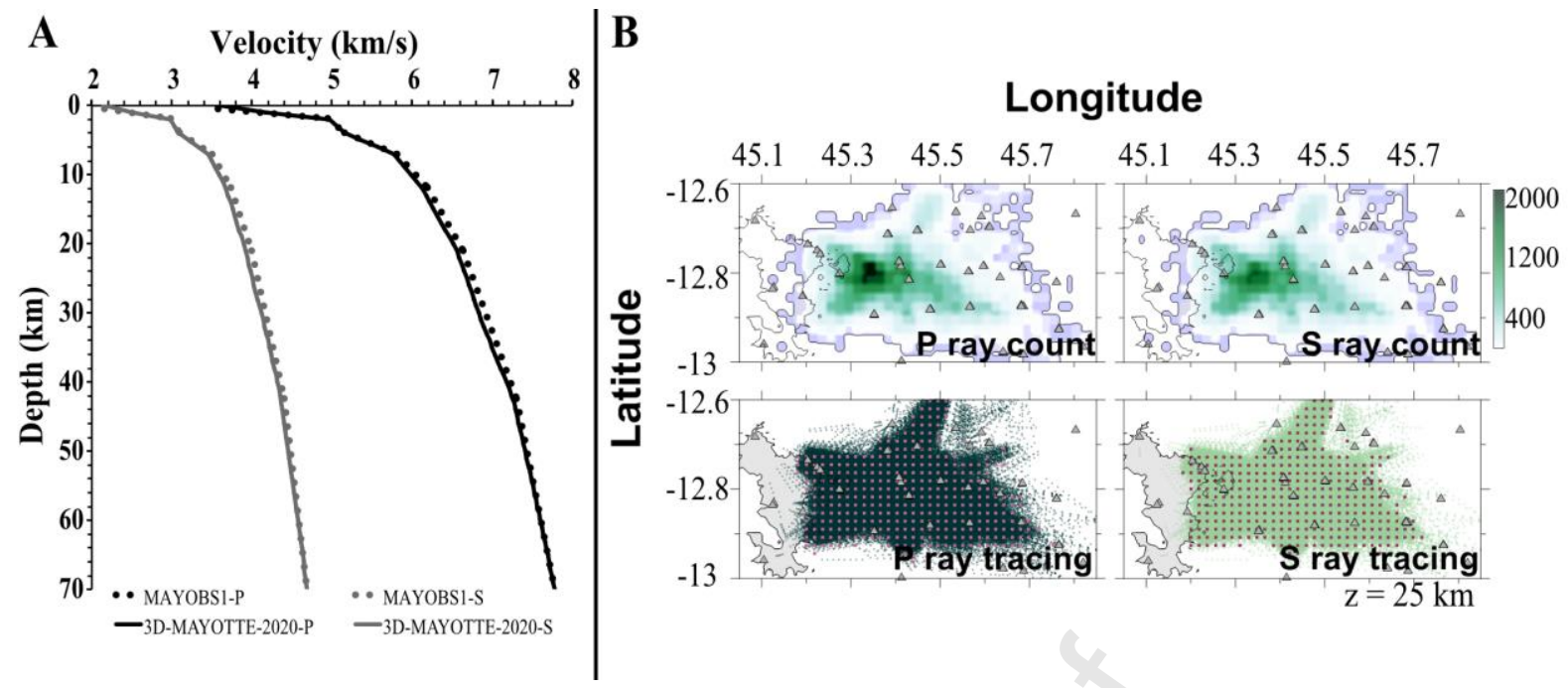

\section{LOTOS parameters for the joint inversion}

\begin{tabular}{|c|c|c|}
\hline Name & Value & Description \\
\hline LSQR ite & 80 & Number of LSQR iteı ation :, the larger value, the sharper solution is \\
\hline Vp wgt / Vs wgt & $1 / 1$ & Weights $\mathrm{P}$ and $\mathrm{S}$ vel city ${ }_{\mathrm{r}}$ arameters \\
\hline P sth / S sth hor. & $0.4 / 0.5$ & Smoothing leve ${ }^{1}$.pp ied in horizontal and vertical directions. The \\
\hline P sth / S sth ver. & $0.2 / 0.4$ & larger value of these parameters, the smoother models become \\
\hline P reg. / S reg. & $0.8 / 1.4$ & $\begin{array}{l}\text { Damf } n g 1 \text {, vel applied. Increasing these parameters induces the de- } \\
\text { crease ol . nomaly amplitudes }\end{array}$ \\
\hline P st. wgt / S st. wgt & $0.0001 / 0.0001$ & Statı - correction weights for $\mathrm{P}$ and $\mathrm{S}$ data \\
\hline Hor. wgt / Ver. wgt & $5 / 5$ & Lo izuntal and vertical weight applied on source shift \\
\hline Time wgt & 1 & Wuight applied on time shift \\
\hline
\end{tabular}

Table 1. LOTOS inversion paramete $\bullet$. Descriptions and values of the parameters used for the inversion. Ite:

Iterations. Wgt: Weight. Hor.: Ho. izr ntal. Ver.: Vertical. Reg.: Regularization. St.: Station.

Fig. 2. Models and ray input overview. A: the dotted lines represent the initial $1 \mathrm{D}$ velocity input models (MAYOBS1) and the solid lines are the average velocity of the 3D velocity model outputs at iteration 3 (3DMAYOTTE-2020). B: example of horizontal cross sections at $25 \mathrm{~km}$ depth for $\mathrm{P}$ and $\mathrm{S}$ ray count, tracing (dark and light green dots) and node distributions (pink dots) in a $0^{\circ}$ grid orientation. Section thickness for nodes and rays visualization is equal to $1 \mathrm{~km}$ each side. Grey triangles mark land and offshore seismic station locations. 


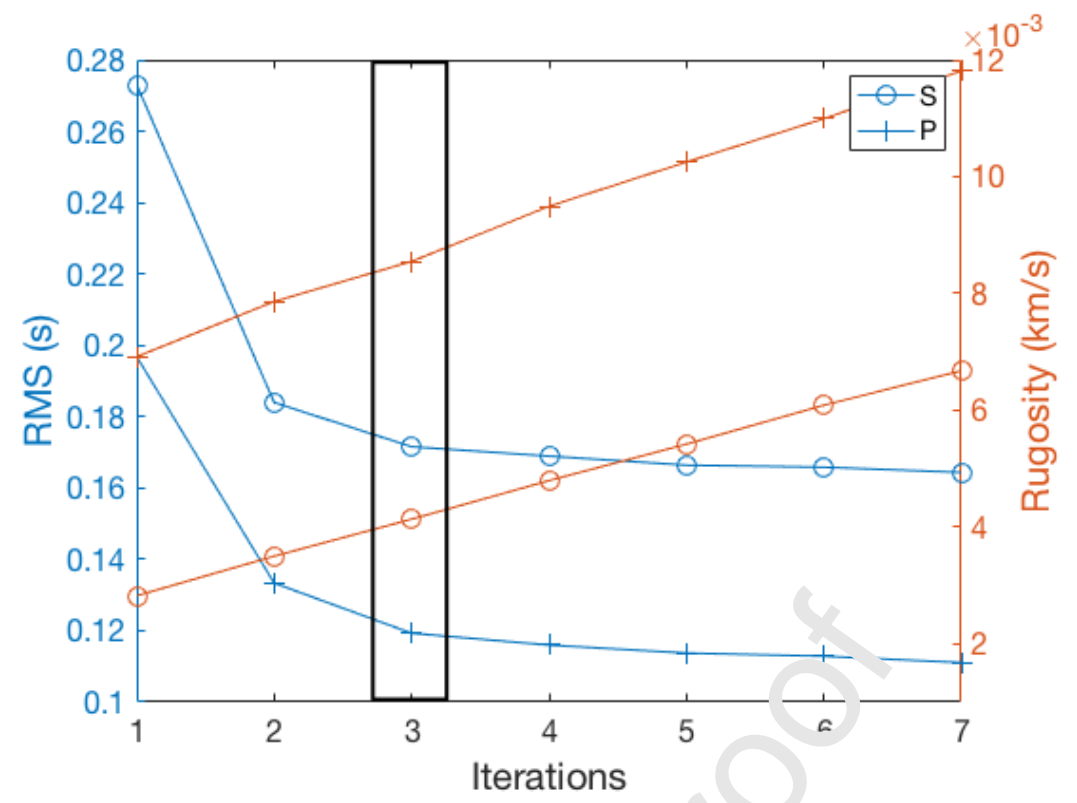

Fig. 3. P and S RMS time residual and roughness per ił_..-9tion for the 3D output velocity model. The black rectangle indicates the chosen iterations.

\subsection{Synthetic tests}

To assess the capacity oi nur dataset to solve the geometry and amplitude of velocity anomalies, we conducted in rizuntal and vertical checkerboard tests, free-shape anomaly tests, and ray coverage and cou 1 t analysis (table 2). Synthetic tests travel times were computed between source-receiver pairs as in the real observation system. They are then perturbed by random noise with an average standard deviation of $0.1 \mathrm{~s}$ for $\mathrm{P}$ and $0.2 \mathrm{~s}$ for $\mathrm{S}$, corresponding to $\mathrm{P}$ and S manual mean of pick time residuals (figure S7). Checkerboard test size was varied from $5 \times 5 \times 100$ to $15 \times 15 \times 100 \mathrm{~km}$ in horizontal map view and from $5 \times 100 \times 5$ to $15 \times 100 \times 15$ $\mathrm{km}^{3}$ with $\pm 10 \%$ of velocity variations for vertical cross-sections. Free-shape anomaly form tests have been determined on the basis of observed patterns resulting from the real data inversion. The latter are set using polygonal forms within defined spatial location and velocity 
anomaly values. Velocity anomalies vary from $\pm 1 \%$ to $\pm 7 \%$. For further understanding of our models limitations, we conducted 3 supplementary synthetic tests. Test 1 demonstrates how isolated structures may be recovered. For test 1, we used another checkerboard test with a $10 \mathrm{~km}^{3}$ size and with $\pm 10 \%$ velocity variation. Test 2 demonstrates the capacity of our model to retrieve horizontally elongated anomalies as sills. For test 2 , we conducted $120 \times 40 \times 10$ $\mathrm{km}$ rectangles along the $-12.8^{\circ}$ direction and $70 \times 60 \times 10 \mathrm{~km}$ rectangles along the $130^{\circ} \mathrm{N}$ direction and inverted with the same velocity variations. Test 3 is another free-shape anomaly forms test, with a Smiley shape as proposed by Koulakov (20n9). ' $n$ test 3, we used $\pm 6 \%$ of velocity variation.

To assess the uniqueness of our velocity anomalies, we changed the 1D velocity model input in LOTOS inversion, and kept original earthr, $\mathrm{ua}_{2}{ }^{-}$locations and inversion parameters similar. We compared here three different moc'a. (f' gure S8):

- "MAYOBS1": previously described aı ${ }^{\gamma}$ iorresponding to the chosen input velocity model.

- “AK-135": spherical Earth averagr ves city model name AK135-F and determined by Kennett et al., (1995), which i: a s autral model for Mayotte region.

- “Alav_simplified": a simpi氵 cieci version of the 1D velocity model developed by Lavayssière et al., (2C 20) sing VELEST. The 1D velocity model was developed using 813 best constrained er ents from February to November 2019 from the same initial cata$\log$ in this study. Lavayssière et al. (2020) used the 1D ADofal model as input. The latter is based on a S-wave velocity profile calculated from receiver functions on the Mayotte Island (Dofal et al., 2018).

Elongated rectangles from $5 \times 5 \times 100$ to $15 \times 15 \times 100 \mathrm{~km}$ size and from $5 \times 100 \times 5$ to 15x100x $15 \mathrm{~km}$ checkerboard and free-shape anomaly tests indicate a good resolution beneath the network with a minimum anomaly size of $5 \mathrm{~km}$ into the PSC (figures 4 to 6 and S9 to $\mathrm{S} 12)$. The $10 \mathrm{~km}^{3}$ also highlight a good recovery between $10 \mathrm{~km}$ and $40 \mathrm{~km}$ depth despite the 
velocity variations with depth (figure S13). This is supported by a good ray coverage and count in the PSC area due to the very active seismicity (figures 2, S14 to S16). The best anomaly shape recovery is obtained with a dimension of $10 \mathrm{~km}$. Anomalies of $15 \mathrm{~km}$ is the upper limit of synthetic anomaly size because of our ray coverage, but it is still quite wellresolved. Synthetic anomalies cannot be solved below $40 \mathrm{~km}$ depth. Our ray coverage does not allow us to resolve velocity variations below the NVE. From the change of 1D input velocity model test, main velocity anomalies are still present as the high P velocity anomaly ( $+3.5 \%)$ and low S velocity anomaly ( -5\%) at $25 \mathrm{~km}$ depth arnim ' the PSC (figure S17). All the anomalies exposed in this study are presented regardles $s c^{c}$ these parameters.

On another hand, elongated rectangles of $120 \mathrm{x} \Delta \mathrm{n}_{\mathrm{\lambda}}{ }^{10} \mathrm{~km}$ along the latitude $-12.8^{\circ}$ and of $70 \times 60 \times 10 \mathrm{~km}$ along the $130^{\circ} \mathrm{N}$ direction could no b w well resolved (figure S18). Only the anomaly around $30 \mathrm{~km}$ depth, where the PSC i 10 , ated, could be retrieved in both $\mathrm{P}$ and $\mathrm{S}$ models. This indicates that our model is 'וn ،ble to image elongated horizontal layers as sills, even if they exist. 
LOTOS parameters for synthetic tests

\begin{tabular}{|c|c|c|c|}
\hline Model Name & Anomaly size (km) & P/S noise (s) & Amplitude of anomalies \\
\hline \multicolumn{4}{|c|}{ Horizontal checkerboard tests } \\
\hline CBHOR_05 & $5 \times 5 \times 100$ & $0.1 / 0.2$ & $\pm 10 \%$ \\
\hline CBHOR_10 & $10 \times 10 \times 100$ & $0.1 / 0.2$ & $\pm 10 \%$ \\
\hline CBHOR_15 & $15 \times 15 \times 100$ & $0.1 / 0.2$ & $\pm 10 \%$ \\
\hline \multicolumn{4}{|c|}{ Vertical checkerboard tests } \\
\hline CBVER_05 & $5 \times 100 \times 5$ & $0.1 / 0.2$ & $\pm 10 \%$ \\
\hline CBVER_10 & $10 \times 100 \times 10$ & $0.1 / 0.2$ & $\pm 10 \%$ \\
\hline CBVER_15 & $15 \times 100 \times 15$ & $0.1 / 0.2$ & $\pm 10 \%$ \\
\hline \multicolumn{4}{|c|}{ Free shape anomaly tests } \\
\hline SYNTHOR1 & Manually digitized & C 1/0.' & Vary from \pm 1 to $\pm 7 \%$ \\
\hline SYNTVER1 & Manually digitized & ¿ $1 / 0.2$ & Vary from \pm 1 to $\pm 7 \%$ \\
\hline SYNTVER2 & Manually digitized & ').1/0.2 & Vary from \pm 1 to $\pm 7 \%$ \\
\hline SYNTVER3 & Manually digitized & $0.1 / 0.2$ & Vary from \pm 1 to $\pm 7 \%$ \\
\hline
\end{tabular}

Table 2. LOTOS parameters for the main sy. the ic test inversions. Descriptions and values of the parameters used for the inversion of synthetic tests. I - wee shape anomalies were manually digitized from the Vs 3D output model. Each anomaly has a given amp to de alue, according to the $3 \mathrm{D}$ output model, and varies from $\pm 1 \%$ to $\pm 7 \%$. 


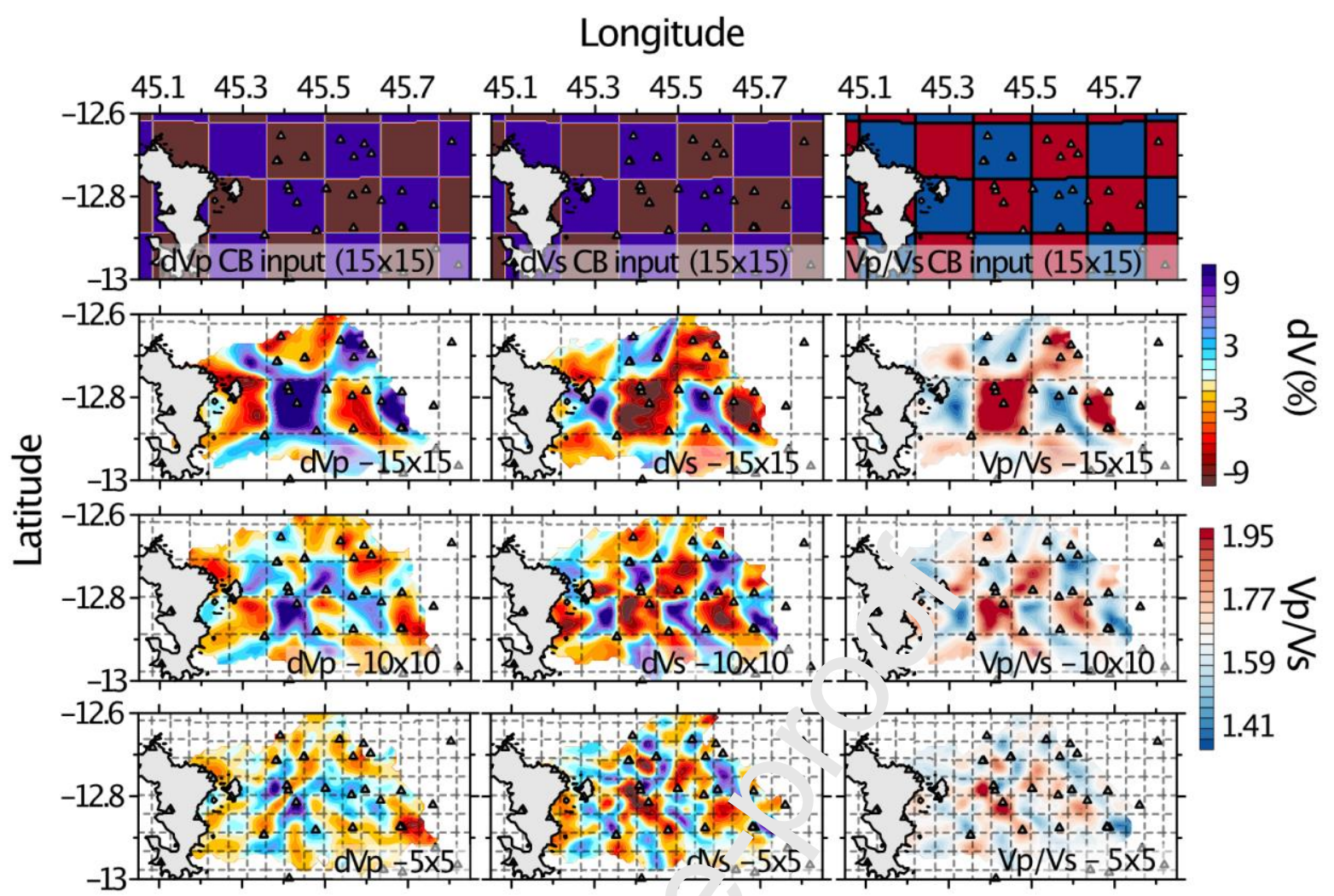

Fig. 4. Horizontal checkerboard tests. Examr' $\sim$ at $\Sigma 5 \mathrm{~km}$ depth of checkerboard tests for $\mathrm{dVp}$ (left), dVs (center) and $\mathrm{Vp} / \mathrm{Vs}$ (right). At the top are 3 examplt. of input. The 3 following lines are output for $15 \times 15,10 \times 10$ and $5 \times 5 \mathrm{~km}^{2}$ square size, respectively. Small tria.. .le: seismometers. Black square: NVE, New Volcanic Edifice. Dashed lines: contour line of the input $c^{h}{ }^{2} \mathrm{ck}{ }^{\text {rl }}$ oard. The white masked area delineates where there are no rays with a distance to the nearest node erial to $2 \mathrm{~km}$.[COLOR NEEDED] 


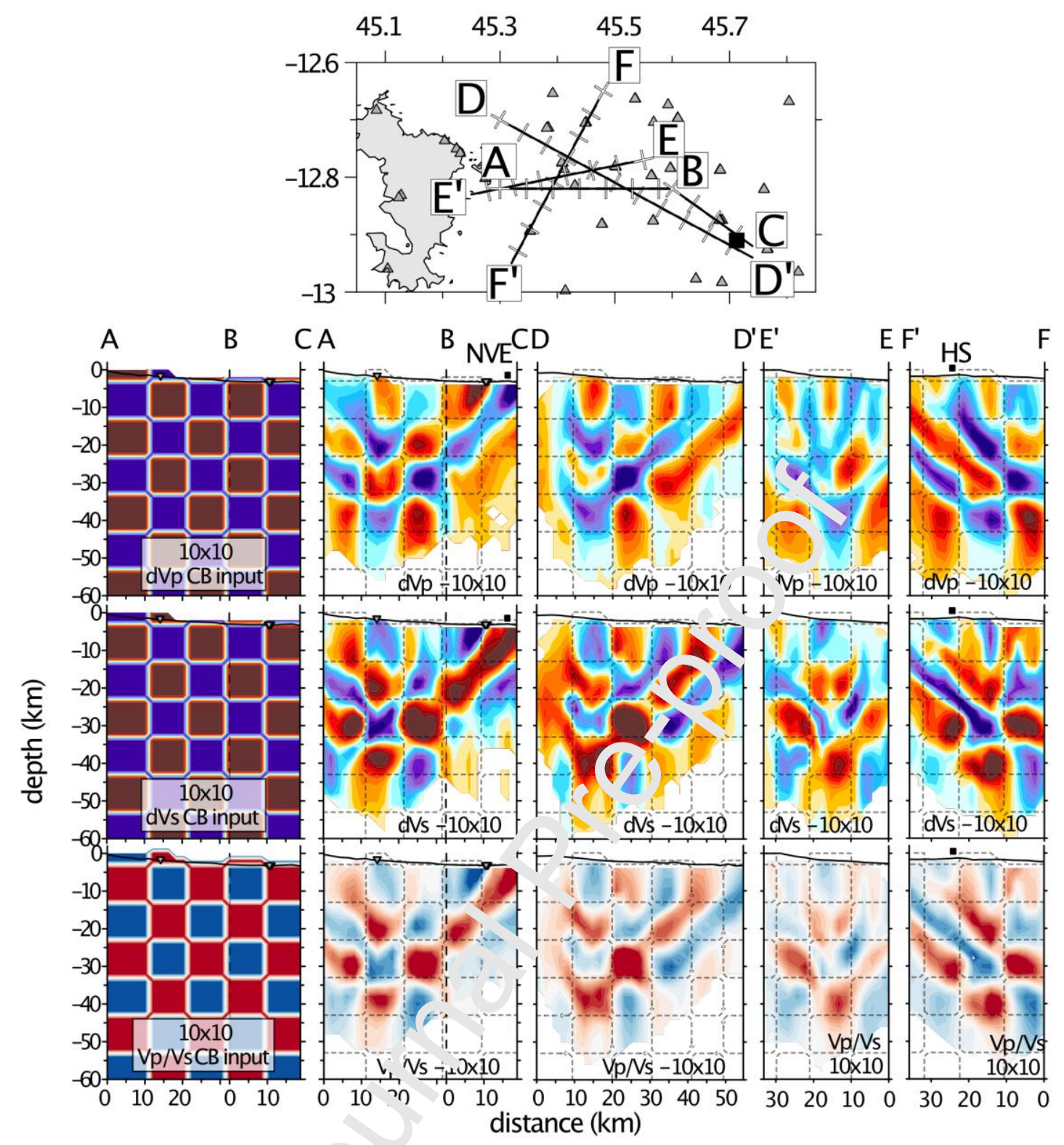

Fig. 5. Vertical checkerb ari to is. Examples of vertical checkerboard tests for $10 \times 10 \mathrm{~km}^{2}$ square size. The 4 cross-sections are indicated the top on the map view. Triangles are seismometers. Left column is an example of input for the $\mathrm{ABC}$ cross-section. The following 4 columns are output for the 4 cross-sections. Top line: $\mathrm{dVp}$. Center line: dVs. Bottom line: Vp/Vs. Color scales are the same as in figure 4. NVE: New volcanic edifice. HS: Horse Shoe. Triangles and dashed lines are explained in figure 4. The white masked area delineates where there are no rays with a distance to the nearest node equal to $2 \mathrm{~km}$. [COLOR NEEDED] 


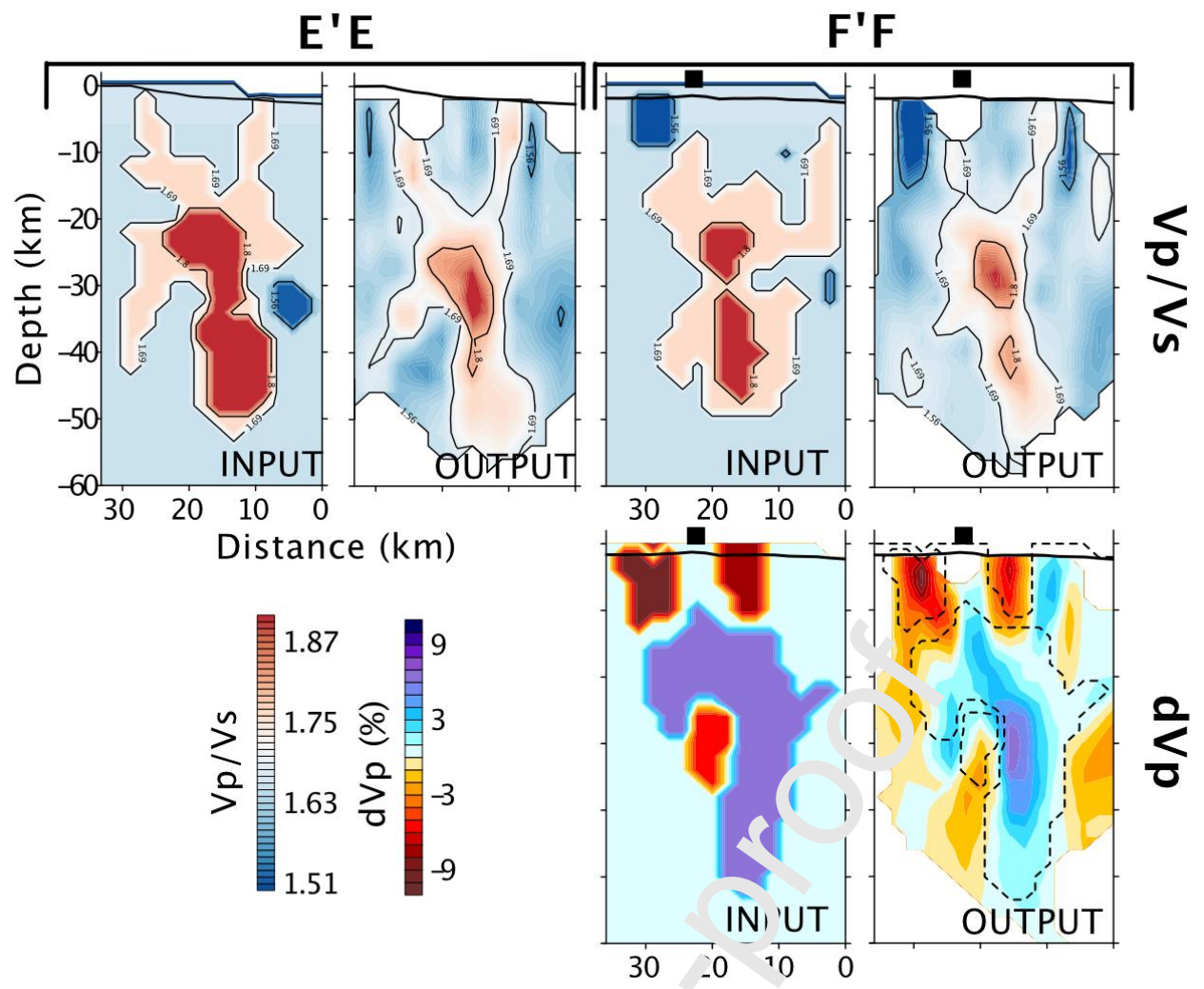

Fig. 6. Free-shaped anomaly tests. Vertical cross-sec io. a amples of free-shaped anomaly tests for EE' and FF' cross-sections. The two cross-sections are ' cat $d$ on the map view on figure 5. INPUT: Input anomalies. OUTPUT: Output after the inversion at iter * ${ }^{\text {ion }}$ 3. Dashed lines on OUTPUT dVp highlight INPUT contours. Black square: Horse Shoe position. The w' tte s' 'sked area delineates where there are no rays with a distance to the nearest node equal to $2 \mathrm{~km}$. [COLOR N.EDED]

To estimate the eits of OBS location uncertainty on the tomographic inversion, we performed two tests, whe e we randomly moved the OBS positions by adding 212 or $424 \mathrm{~m}$ on the azimuthal plane (figure S19, S20). We found that the anomaly shapes were not strongly influenced and that only a small change in the amplitude occurred. The estimated effect on the $\mathrm{dVp}$ and $\mathrm{dVs}$ models on 4 horizontal cross sections at $10,15,25$ and $35 \mathrm{~km}$ depth is $\sim 0.25$ $\pm 5.78 \%(\mathrm{dVp})$ and $\sim 0.50 \pm 9.03 \%(\mathrm{dVs})$ for a $212-\mathrm{m}$ mislocated OBS (figure S19) and $\sim 0.35$ $\pm 6.71 \%(\mathrm{dVp})$ and $\sim 0.65 \pm 10.08 \%(\mathrm{dVs})$ for $424 \mathrm{~m}$ (figure S20). Large uncertainty values are only present at the edge of the models, mainly around the NVE area, where there are not enough rays crossing. The models are therefore not strongly affected by the uncertainty of 
OBS locations and do not prevent us from interpreting our final tomographic inversion. However, this uncertainty has to be taken into consideration if another passive tomography is calculated in the same area, with the aim of exploring the evolution with time of the volcanic plumbing. As the seismic network will be different, the velocity variations between this tomography and the new calculated one have to be higher than the latter calculated uncertainties.

\section{Results}

\subsection{Velocity models}

Figures 7 and 8 illustrate our 3D velocity more $\mathrm{I}_{\mathrm{s}}(\mathrm{Vp}, \mathrm{dVp}, \mathrm{Vs}, \mathrm{dVs}$ and $\mathrm{Vp} / \mathrm{Vs})$ in horizontal and vertical cross-sections, respectively. Nota 7 le anomalies are labeled from 1 to 6 , as indicated on $\mathrm{Vp} / \mathrm{Vs}$ cross-sections or map , , r rot surcharge the figure, even if they are present in the other models. Some supp' $m f$ atary cross-sections of $d V p$ and $d V s$ models may be found in figures S21 to S24, as welı is a video (video V1) of the Vp/Vs model.

In general, besides the hiøhli_r. ed structures we call «velocity anomalies » in this study, the overall Vp and Vs ri: des present really low velocity in the crust and in the mantle. Taking a Moho at $17 \mathrm{~km}$ ( $\mathrm{L} 、 \mathrm{f}_{\curvearrowright} /$ et al., 2018), the mean $\mathrm{Vp}$ in the crust is equal to $5.6 \mathrm{~km} / \mathrm{s}$ and Vs to $3.3 \mathrm{~km} / \mathrm{s}$, whi ${ }^{-h}$ is lower than typical values for oceanic crust $(6.5-7 \mathrm{~km} / \mathrm{s}$ for $\mathrm{P}$ and $4 \mathrm{~km} / \mathrm{s}$ for S). For deep depths, for example at $30 \mathrm{~km}$ depth (figures $1-\mathrm{A}$ and 7 ), $\mathrm{Vp}$ is lower than $8 \mathrm{~km} / \mathrm{s}$ and Vs lower than $4.4 \mathrm{~km} / \mathrm{s}$, which are typical values for uppermost mantle. The approximate mean $\mathrm{Vp}$ is about $6.8 \mathrm{~km} / \mathrm{s}$ and $\mathrm{Vs}$ is about $4.1 \mathrm{~km} / \mathrm{s}$. What we will later refer to « fast» and « low» velocity anomalies are relative to these observations. We cannot exclude that the first $10 \mathrm{~km}$ are less resolved because of ray crossing geometry (figure S15 and S16) and are therefore more influenced by the input velocity model.

A first striking anomaly is observed between depths of 20 and $35 \mathrm{~km}$, below the Horse 
Shoe (HS), in the PSC area (figures 7-8, labeled 1). Its diameter varies from 7 to $12 \mathrm{~km}$, and it can be imaged by our inversion. Anomaly 1 is characterized by low $\mathrm{Vp}(<6.8 \mathrm{~km} / \mathrm{s})$, low Vs $(<3.9 \mathrm{~km} / \mathrm{s})$, low $\mathrm{dVp}(>-3 \%)$ and low $\mathrm{dVs}(>-4 \%)$. The $\mathrm{Vp} / \mathrm{Vs}$ ratio ranges from 1.8 to a maximum value of 1.92 in its center. Considering an isosurface of $\mathrm{Vp} / \mathrm{Vs}$ ratio equal to 1.8

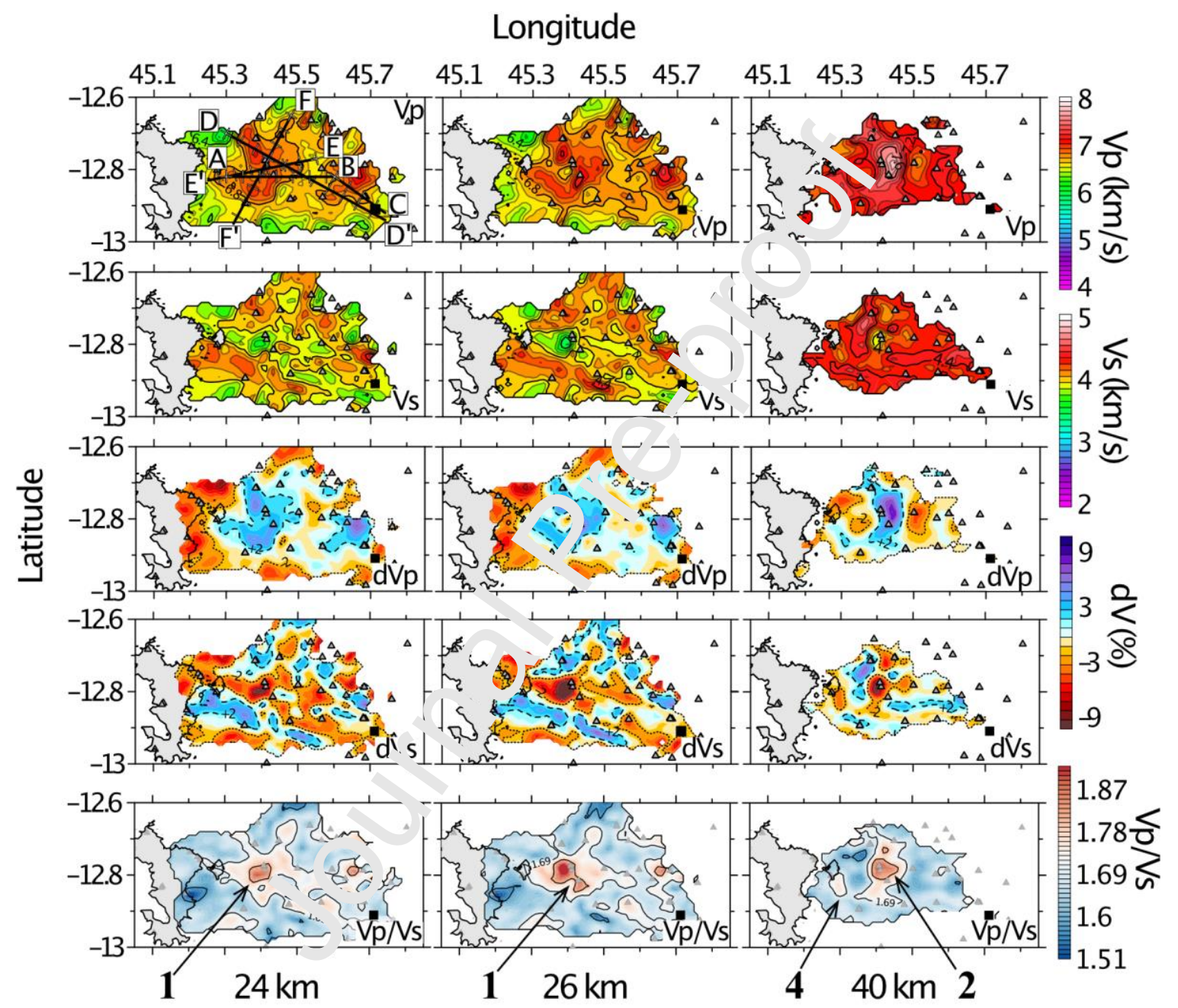

using Voxler (Golden Software), we obtained a volume of this body equal to $205 \mathrm{~km}^{3}$.

Fig. 7. Horizontal cross-sections of the output velocity models. Horizontal cross-section at 24 (left column), 26 (center column) and 40 (right column) km depth for Vp, Vs (top lines); $\mathrm{dVp}$, $\mathrm{dVs}$ (center lines) and Vp/Vs (bottom line). Mayotte islands are represented in light grey. Triangles are seismometers used for the study. Vertical cross-section illustrated on figure 8 are located on the top-left map and on figure 5. The black square marks the location of the NVE. The white background masks indicate the area where there are no rays. Vp, Vs: solid black lines are isovelocity contours every $0.4 \mathrm{~km} / \mathrm{s}$; solid light lines are isovelocity contours every $0.1 \mathrm{~km} / \mathrm{s}$. 
$d V p, d V s$ : black dashed lines are the $+2 \%$ isocontours; block dotted lines are the $-2 \%$ isocontours. $V p / V s$ s solid black lines indicate two isocontours: 1.68 and 1.8. The large black numbers $(1,2$ and 4$)$ indicate anomalies described in Section 3. [COLOR NEEDED] 
Fig. 8. Vertical cross-sections of the output velocity models. Symbols and notations are the same as in figure

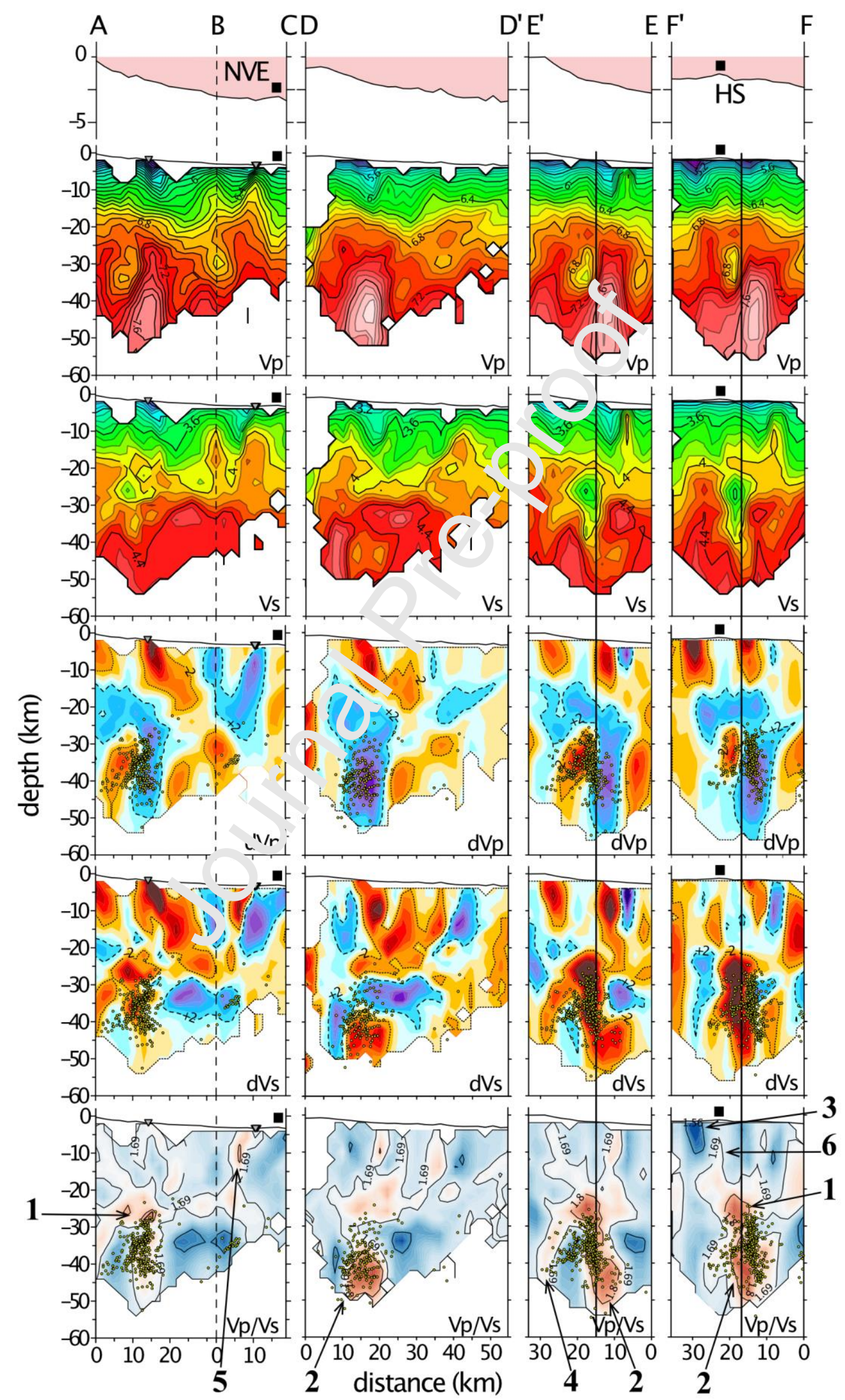


7. From top to bottom: A bathymetry exaggeration, $\mathrm{Vp}$ and $\mathrm{Vs}, \mathrm{dVp}$ and $\mathrm{dVs}$, and $\mathrm{Vp} / \mathrm{Vs}$ images. Yellow dots on $\mathrm{dVp}, \mathrm{dVs}$ and $\mathrm{Vp} / \mathrm{Vs}$ cross-sections are earthquake locations on a slice of $1 \mathrm{~km}(0.5 \mathrm{~km}$ each side $)$. Traces of the cross-sections and color scales are shown in the figure 7. The black squares indicate the position of the NVE (New volcanic edifice) and the HS (Horse Shoe) bathymetric feature. The black dashed vertical line on the ABC cross-section indicates the position of the change in the section orientation. The black vertical solid lines on EE' and FF' cross-sections are a visual support to easily observe the limit between the anomalies 1 and 2 . [COLOR NEEDED]

A second notable elongated anomaly is observed between. depths of 35 and $50 \mathrm{~km}$, in the same region, slightly East of anomaly 1, in the PSC aren (1,oures 7-8, labeled 2). Its width and length vary from 8 to $17 \mathrm{~km}$. The anomaly can be : maged, but our inversion cannot recover well velocity variations below $\sim 43 \mathrm{~km}$ depth, raking any interpretation below that depth as speculative. Only the top of this anoı $: 1 y$ is recovered by our free-shape anomaly tests (figure 6). Anomaly 2 is characteri ed sy high $\mathrm{Vp}(>7.2 \mathrm{~km} / \mathrm{s})$, heterogeneous Vs, high $\mathrm{dVp}(>+2 \%)$ and heterogeneous $\mathrm{dVs}>+2 \%$ around $30-35 \mathrm{~km}$ depth and $<-2 \%$ around $40-$ $50 \mathrm{~km})$. The $\mathrm{Vp} / \mathrm{Vs}$ ratio varies from ${ }^{\prime} .6$ s to more than 1.8 in the lower and eastern part. Considering a $\mathrm{Vp} / \mathrm{Vs}$ ratio isosurface o. 1.8 , the volume of anomaly 2's body is equal to $234 \mathrm{~km}^{3}$, but this volume could be 0 ar 11 underestimated as we do not have resolution below $43 \mathrm{~km}$ depth.

A third feature is observed on the cross-section FF', between 0 and $10 \mathrm{~km}$ depth, South of the HS, $25 \mathrm{~km}$ away from Petite-Terre (figure 8, labeled 3). Its width and length is equal to $5 \times 5 \mathrm{~km}^{2}$, in a region where an anomaly of this size is at the limit of resolution (figure $\mathrm{S} 11$ ). A free-shaped anomaly test (figure $6, \mathrm{FF}^{\prime}$, blue high $\mathrm{Vp} / \mathrm{Vs}$ ratio and red low $\mathrm{dVp}$ at 30 $\mathrm{km}$ of distance) indicates that this anomaly could be resolved but appears a bit bigger than in reality. Anomaly 3 is characterized by very low $\mathrm{Vp}(\sim 4.8 \mathrm{~km} / \mathrm{s})$, no apparent change in the Vs model, very low $\mathrm{dVp}(<-8 \%)$, and no apparent change in $\mathrm{dVs}$. The $\mathrm{Vp} / \mathrm{Vs}$ ratio is about 1.50 1.56, with a minimum of 1.44 into the center. Considering a $\mathrm{Vp} / \mathrm{Vs}$ isosurface equal to 1.56 , 
anomaly 3's body volume is equal to $42 \mathrm{~km}^{3}$, but this volume is likely overestimated as our free-shape anomaly test indicates.

Anomaly 4 is a nearly vertical branch just below Petite-Terre that extends from anomaly 1 (cross-section EE', figure 8). This nearly vertical branch is located between 30 to 47 $\mathrm{km}$ in depth. Its width is about $8 \mathrm{~km}$, and according to a free-shaped anomaly test this branch is resolvable (figure 6 and S25). Anomaly 4 is characterized by a small decrease in Vp and Vs, illustrated by a U-shape in the isovelocity contours (figure 8). In the $\mathrm{dVp}$ model, we cannot distinguish anomaly 1 from 4; they seem to be connected. In thi dVs model, we can clearly observe a branch from anomaly 1 with decreasing dVs (II $-\mathrm{m}-2$ to $-4 \%$ ). Anomaly 4 has a $\mathrm{Vp} / \mathrm{Vs}$ ratio of about 1.72 .

The $5^{\text {th }}$ notable anomaly is located between 3 an ${ }^{r} 15 \mathrm{~km}$ depth, West of the NVE and seemingly "pointing" in the direction of the $\mathrm{I}^{\mathrm{r}} \mathrm{r}$ (, ross-section $\mathrm{BC}$, figure 8). Its width and length are about $5 \mathrm{~km}$, in a region wh re his anomaly size could be solved (figure S11). Anomaly 5 is characterized by a slighı tecrease in $\mathrm{Vp}$ and $\mathrm{Vs}$. The $\mathrm{dVp}$ model does not give relevant velocity variation. The $\mathrm{d}^{\mathrm{V}} \mathrm{n} \mathrm{n}_{\mathrm{A}}$ el is characterized by a very low velocity anomaly $(<$ $-4 \%$ ). The Vp/Vs ratio is highc than 1.8 in this region. More to the East, below the NVE, the resolution is not sufficient to drtermine any remarkable anomaly. Considering an isosurface equal to 1.8 , we obtaint ${ }^{\wedge}$ a volume for this anomaly body to be equal to $94 \mathrm{~km}^{3}$.

Anomaly 6 has a vertical elongated shape and extend from the top of the anomaly 1 to the subsurface, below the HS relief (cross-section FF', figure 8). Its length is about $9 \mathrm{~km}$, making it resolvable (figure 6). Anomaly 6 is characterized by slight increase in $\mathrm{Vp}$, and a slight decrease in Vs. The $d V p$ model doesn't give relevant velocity variation. In the dVs model, the anomaly has an amplitude equal to $+2.5 \%$. The $\mathrm{Vp} / \mathrm{Vs}$ is slightly higher than 1.71 .

Finally, taking an isocontour $\mathrm{Vp} / \mathrm{Vs}$ ratio equal to 1.69 , we observed several branches that connect the different anomalies $(1,2,4,5$ and 6) to each other $(\mathrm{Vp} / \mathrm{Vs}$ ratio on figure 8). 
Anomaly 1, appears to be a central anomaly with several branches emerging both up and down, reaching the surface and connecting to seafloor reliefs (cross-sections DD' and FF', figure 8), and going East, toward the NVE (cross-section ABC, figure 8). In horizontal crosssections (24-26 km depth, figure 7), the branches have a $\mathrm{N} 130^{\circ}$ orientation in the $\mathrm{dVs}$ and $\mathrm{Vp} / \mathrm{Vs}$ models, parallel to the volcanic ridge. However, the $\mathrm{dVp}$ model does not provide any relevant velocity variations. To exclude the possibility of an artifact, we conducted three different tests. First, we inverted our data into the four grid orientation (Section 2.3) proposed by LOTOS to evaluate the influence of the nodes on the N130 anof aly $\left(0^{\circ}, 22^{\circ}, 45^{\circ}\right.$ and $\left.66^{\circ}\right)$. Regardless of the grid we used, the anomaly persists (fig alc So). Next, we explored the influence of the $1 \mathrm{D}$ velocity input (Section 2.3). No matter :he $1 \mathrm{D}$ input model, the $\mathrm{N} 130^{\circ}$ anomaly still exists (figure S8). Finally, we inverted a frze - hape anomaly test based on the later anomaly shape to be sure that our data may re $: 0$ er .t. The output velocity from this test indicates that the $\mathrm{N} 130^{\circ}$ anomaly is recoverc ${ }^{-1}$ a ite well (figure $\mathrm{S} 26$ ).

\subsection{Seismicity distribution}

Figure 8 displays earth: 'lakt locations obtained after the inversion. Their average displacement in longitude, latitu de, and depth from the filtered catalog at iteration 3 are respectively equal to $1.43,1 . \mathrm{c}^{\text {? }}$ and $1.27 \mathrm{~km}$. Seismicity is primarily concentrated in PSC, which is an elongated cluster in the vertical direction, between 25 and $55 \mathrm{~km}$ depth. This seismicity delineates $\mathrm{dVp}$ positive and negative amplitudes between anomalies 1 and 2 (sections $\mathrm{ABC}$, $\mathrm{EE}$, and FF', figure 8). In the $\mathrm{dVs}$ model, it is difficult to associate the seismicity distribution to velocity changes, except along section FF' where the earthquakes are well aligned South of the negative anomaly. On the Vp/Vs sections, the PSC is well associated with the South and West border of the $1.8 \mathrm{Vp} / \mathrm{Vs}$ isocontour. In section $\mathrm{BC}$, several events associated with DSC form a dipping alignment pointing toward the NVE. 


\section{Discussion}

From our 3D velocity models, we propose to interpret the velocity anomalies as possible multiple magmatic reservoirs between the mantle and crust, and we discuss the old plumbing system between these reservoirs, the occurrence of gases, and the role of the inheritances.

\subsection{Low velocity crust and mantle}

Low $\mathrm{P}$ and $\mathrm{S}$ velocities characterizing the crust cr uli be explained either by the presence of gas (HS has observable degassing), the presence of multiple fractures and cracks due to regional strain (Feuillet et al., 2021; Famin et al., 2v.')), or by the basaltic composition of the crust (Berthod et al., 2021). Unfortunately, t. - fi ist $10 \mathrm{~km}$ are less resolved because of ray crossing geometry. Further study is in ${ }_{1}$ ror ess to learn more about the crust through active seismic imagery (Sismaore marine cruı ${ }^{\circ}$, Thinon et al., 2020). At slightly deeper depths, the Moho has been determined to be at 1'. $1 \mathrm{~m}$ (Dofal et al., 2018). From our study, the velocities below $30 \mathrm{~km}$ depth are about $C 9 \mathrm{kn} / \mathrm{s}$ for the $\mathrm{Vp}$ and highly perturbed. Moreover, the overall area seems to have very lov: I p and Vs. Darnet et al. (2020) conduced a magnetotelluric (MT) survey through $\mathbf{t}+\mathrm{l}$ - Terre and the PSC. The MT survey indicated the presence of a drop (two orders of magnitude) in the rock resistivity at about $15 \mathrm{~km}$ depth. Changes in rock resistivity can be influenced by hydrothermal and/or magmatic fluids. Darnet et al. (2020) interpreted this resistivity drop as possibly due to partial melting. As discussed by Feuillet et al. (2021), the lithosphere-asthenosphere boundary in place between Mayotte and Madagascar is composed of a high-velocity lithosphere and a low-velocity asthenosphere. Barruol et al. (2019) interpreted the low-velocity asthenosphere as hot material spreading beneath and beyond the Mascarene basin. Hot oceanic lithosphere base combined with a damaged mantle 
and crust, induced by regional rifting, may favor large volumes of melts (Feuillet et al., 2021). The latter hypothesis may be illustrated in our study by these low $\mathrm{P}$ and $\mathrm{S}$ velocities, suggesting for a widespread melt throughout the region.

Our interpretations of Mayotte's volcanic system mainly benefit from Lees (2007), which gives an overview of seismic tomography of magmatic systems. Fractured rocks, the lithological nature of rocks, the presence of water, oil, gas, or magmatic fluids, and anisotropy may have an influence on the $\mathrm{Vp} / \mathrm{Vs}$ ratio. Comparing $\mathrm{Vp} / \mathrm{Vs}$ ratio with $\mathrm{Vp}$ (or $\mathrm{dVp}$ ) and $\mathrm{Vs}$ (or $\mathrm{dVs}$ ) values and geological information of the area is crucial ivr interpreting tomography results. Using Mayotte stations (local) and Glorieuse and na thala stations (regional) gave a local and regional $\mathrm{Vp} / \mathrm{Vs}$ ratio mean determined from $1 \mathrm{v}$ : 4 YOBS data to be 1.66 and 1.72 , respectively (Lavayssière et al., 2020; Saurel et al., rssu `mitted). These Vp/Vs ratios fall between 1.5 and 2 , which are generally acc $\cdot \mathrm{p} \cdot \mathrm{d}$ for more consolidated rock materials. Lavayssière et al., (2020) highlight a $7 \mathrm{~km}$-layer with a $\sim 1.8 \mathrm{Vp} / \mathrm{Vs}$ ratio indicative of the magmatic nature of the crust, upon a $: 6 \mathrm{Vp} / \mathrm{Vs}$ ratio below $10 \mathrm{~km}$ that they interpret as influenced by faulting and/or the prose. ${ }^{\circ}$ of fluids. While, sandstones can have $\mathrm{Vp} / \mathrm{Vs}$ ratios varying from 1.66 to 1.81 and arbunates from1.81 to 1.98 (e.g. Hamada 2004), the nature of the Comoros basin remains u. ${ }^{1} \operatorname{sar}$ (Phethean, 2016). Therefore, it is difficult to make a direct comparison of our $\mathrm{Vp} /{ }^{\top} \mathrm{c}$ values with oceanic or continental crust $\mathrm{Vp} / \mathrm{Vs}$ values. Based on the works cited above, and because our results are mainly concentrated below $10 \mathrm{~km}$ depth, we consider everything higher or lower than the $\mathrm{Vp} / \mathrm{Vs}$ local mean (1.66) as an anomaly.

\subsection{Multiple reservoirs}

Anomaly 1 ( $28 \mathrm{~km}$ depth beneath HS), defined by low dVp and dVs and high Vp/Vs ratio (more than 1.8) could be characteristic of the presence of mush and partial melt (e.g. Nakajima et al. 2001; Lees 2007). This combination of low Vp and high Vp/Vs ratio may also reflect a strongly fractured body filled with fluids (Bazin et al., 2010). After dredging the HS 
region, Berthod et al. (in press) conducted a geobarometry analysis on two xenoliths pyroxenes. They identified the presence of a shallow reservoir, located just below the crust and mantle boundary, storing phonolitic magma. We can make the hypothesis that anomaly 1 could be an evolved reservoir, corresponding to the Berthod et al. (in press) phonolitic reservoir, responsable to the HS volcanism. The VLF seismic activity has been located in the same area (Laurent et al., 2020), where Feuillet et al. (2021) proposed the existence of a reservoir. We rename it as reservoir B (Figure 9).

The depth of anomaly 1 is in agreement with GNSS modelı $\mathrm{g}$ of Lemoine et al. (2020)

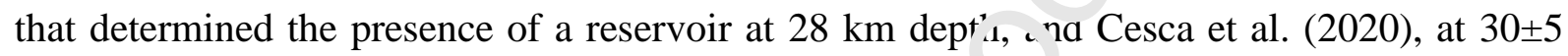
$\mathrm{km}$. Through VLFs modeling, the latter authors determund a reservoir diameter of about 12 $\mathrm{km}$ and 10 to $15 \mathrm{~km}$ respectively. This is consistent $\mathrm{w}_{1 .}{ }^{n}$ our findings, as we determined the diameter of anomaly 1 varying from 7 to $12 \mathrm{k}$. I Iowever, they both located the reservoir further East, at about $30 \mathrm{~km}$ from the cc.'st ' .e., Lemoine et al., 2020), whereas Feuillet et al. (2021) determined a deflation source a $10 \mathrm{~km}$ far from the coast and at $40 \mathrm{~km}$ depth. Because of poor azimuthal coverage, longitıdı $i$, less constrained. Taking into account the combined errors on GNSS modeling anc' tomugraphy inversion, anomaly 1 and the reservoir identified by Lemoine et al. (2020) anı C ssca et al. (2020) could be the same or distinct body. Indeed, the GNSS modeling de. 'onstrated an overall deformation and could not distinguish if several reservoirs are involved. The GNSS inversion could be a combined result of anomaly 2 and a reservoir bellow the NVE effects. We cannot exclude the possibility of a reservoir at 30-40 $\mathrm{km}$ far from the coast that we are unable to image in this study due to ray coverage.

Anomaly 2 ( 44 km depth) is defined by high Vp, low Vs, and high Vp/Vs ratio (larger than 1.8) which seems to be an indicator of liquid phase, volatiles, or melts (De Natale et al., 2004; Vargas et al., 2017; Kuznetsov et al., 2017). In volcano tomography studies, this could represent a magma reservoir with more primitive composition of mafic magmatic cu- 
mulates, saturated with volatiles that may carry a gas phase (e.g. Lees 2007; Lin et al., 2013; Vargas et al., 2017; Koulakov et al., 2020). On the other hand, a high Vp may be interpreted as an old solidified intrusion/magma chamber, and the corresponding high $\mathrm{Vp} / \mathrm{Vs}$ may be interpreted as over-pressurized fluids and/or faults (e.g. Feuillet et al., 2004). Anomaly 5 ( 10 $\mathrm{km}$ ) is marked by low $\mathrm{Vs}$, high $\mathrm{Vp} / \mathrm{Vs}$ ratio (up to 1.8), and no significant variation of the $\mathrm{P}$ velocities. Depths of anomalies 2 and 5 coincide with two reservoirs identified by Berthod et al. (2021) through geobarometric analysis on clinopyroxene of dredges made on the NVE in 2019. Berthod et al. (2021) identified a large reservoir at $368-48.0 \pm 10 \mathrm{~km}$ depth and a smaller reservoir, with a maximum depth of $17.1 \pm 6.5 \mathrm{kr} .1$. Their large reservoir may correspond to our anomaly $2(\sim 44 \mathrm{~km}$ depth), and their smalı * reservoir may correspond to anomaly 5 ( 10 km depth). From our analysis, anomaly 2 - an be interpreted as an old solidified intrusion that is still in use as a reservoir, whe it: $s$ nomaly 5 could be a shallower reservoir. However, we cannot exclude that anom ' $\mathrm{v}$ '; does not present variation in the P velocity model and that it could be located above $10 \mathrm{~km}$. At that depth, the ray geometry induced a decrease of the general resolution and trion corrections may have an influence. The coincidence with anomaly 5 and oth $r$ studies will need further investigation, such as local active tomography, to learn more ain the volcanic plumbing near the NVE. We consequently rename anomalies 2 as re ${ }^{2}$ rvulr A and anomaly 5 as hypothetical reservoir $\mathrm{C}$.

From earthquake locations, Lavayssière et al. (2020) relocated events in the PSC cluster, and this seismicity well delineates reservoirs A and B with an hourglass shape. As stated in Lavayssière et al. (2020), the seismicity could be correlated with the inflation and deflation of the magma reservoirs due to fluid migrations. Because of the high amount of gas at the NVE and HS (Feuillet et al., 2021), we cannot exclude that a part of the seismicity may be attributed to fracturing due to high pressure on magma reservoirs. A similar interpretation was made for the Nevado del Ruiz volcano, for example (Vargas et al. 2017). The presence of gas 


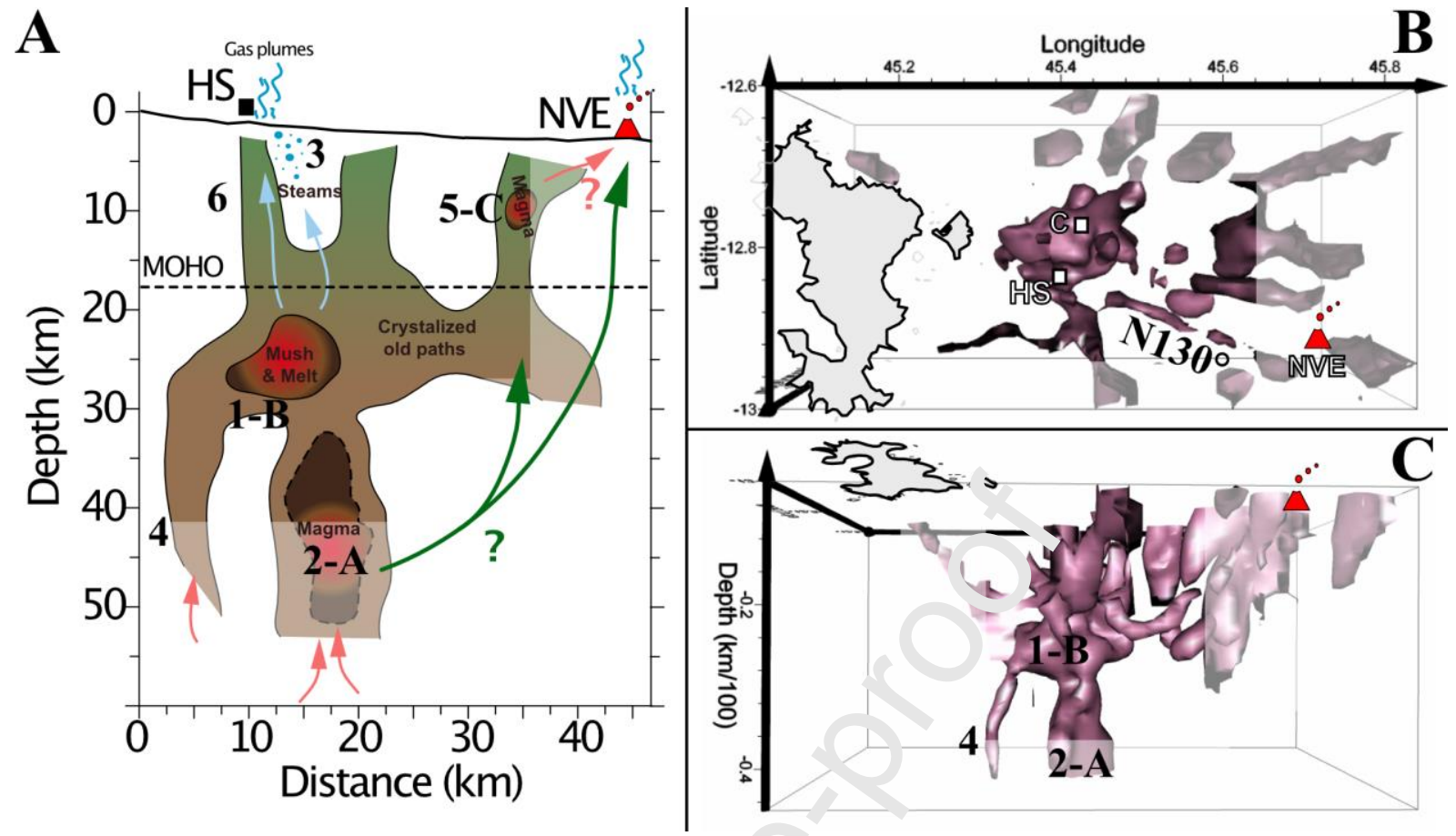

may consequently explain the low $\mathrm{Vp} / \mathrm{Vs}$ ratin in … se areas (report to 4.3).

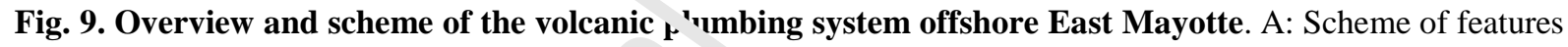
interpreted from the passive tomography. Ke I s crow: magmatic fluids potential feeding paths. Blue arrow: gas escape to seafloor and water column. Jru $\eta \eta$ arrow: ongoing magmatic eruption path. The green to brown shaded structure highlights old volcanic crys 'llized paths. Moho depth is from Dofal et al. (2018). HS: Horse Shoe. NVE: New volcanic edifice. Jumı ers from 1 to 6 and letters from A to C are anomalies described in Section 3 and 4. Degassing at the HS an ' NVE is from Feuillet et al. (2021) and REVOSIMA reports. The white masked area indicates areas that are not well resolved or not at all resolved. B: Vp/Vs 3D view from the top of the volcanic plumbing system highlighted by an isosurface equal to 1.71 . The letter $\mathrm{C}$ indicates the Crown structure position. C: same as B with a view of the system from the South.

\subsection{Reservoirs interactions}

According to previous GNSS modeling (e.g. Lemoine et al, 2020), a deep deflation at $30 \mathrm{~km}$ East of Mayotte and at $30 \mathrm{~km}$ depth and below was identified. This deflation related to our new seismic imagery support the idea of magmatic fluids being transferred from the PSC 
region. Events in the DSC have been relocated and partially highlight a fluid pathway between reservoirs A and C, toward the NVE (Lavayssiere et al., 2020). This path was expected by Berthod et al. (2021) and proposed by Feuillet et al. (2021), Cesca et al. (2020), and Laurent et al (2020). However, the lack of seismicity at that depth or below the expected fluid pathway makes it impossible to recover the pathway using passive local tomography. Since autumn 2020, seismicity has increased in the DSC, even though overall the seismicity rate in the region has decreased (REVOSIMA, October and November reports). The reports indicate that the increase of seismicity in the DSC delineates a dipping st' 1 cture between $40-50 \mathrm{~km}$ depth that links to the PSC. As the eruption at the NVE is mi ongoing, this seismic activity is one more clue to the hypothesis that a path between resu "voir A and the NVE exists (green arrow on figure 9). These earthquakes will be used fvrtı ${ }^{2}$ for a new updated tomography and hopefully will increase the resolution near the $V^{\prime} \cdot$.

Cesca et al. (2020) proposed tha ${ }^{+}$V LFs events (also known as VLP, for Very Long Period) are the result of the interaction - $f$ the seismic wave with a fluid-filled crack or conduit at a depth of $37+/-11 \mathrm{~km}$. On the otl e hand, Laurent et al. (2020) relocated VLFs to be between 10 and $30 \mathrm{~km}$ depths. In soth cases, VLFs are likely linked with fluid migrations and/or resonance (Chouet, 1985: Kım igai et al, 2003; Talandier et al., 2016). Laurent et al (2020) specified that dependin, on the depth, the VLFs could be related to magma motion or hydrothermal fluids. Two hypothesis remain here. One hypothesis is the existence of a deep hydrothermal circulation along preexisting faults. Indeed, the PSC seismicity is thought to use preexisting subvertical faults (Jacques et al. 2019), reactivated by the depletion of reservoir A as observed during caldera collapse (Feuillet et al., 2021). The pre-existing sub vertical faults may be used for hydrothermal circulation. A second hypothesis is that VLFs, ranging between 10 to $30 \mathrm{~km}$, highlight gas transport along pre-existing faults or conduits from reservoir B to the HS area (blue arrow on figure 9). In fact, Berthod et al. (in press) identified the presence 
of a shallow reservoir, after dredging the HS region, storing phonolitic magma derived from differentiation of basanite. If we made the hypothesis that this reservoir may correspond to our reservoir B, a potential re-injection of basanitic magma (less viscous) into the reservoir could be responsible for degassing observed at HS. Such large degassing from basanitephonolite magmas has been observed in the Canary Islands (Tenerife, Edgar et al., 2007) and at Erebus volcano (Oppenheimer et al. 2009). Our results better support the latter hypothesis that will be discussed in the next section.

\subsection{Gas storage?}

The $\mathrm{Vp} / \mathrm{Vs}$ ratio parameter is mainly informative, as it is highly sensitive to the presence of liquid and gas. The HS area is known for its $\mathrm{g}_{a}$ emission. In December 2019, 3 gas acoustic plume sites were identified, some of the a $r$ aching $1000 \mathrm{~m}$ high in the water column (Feuillet al., 2021). Below the HS struc 're, we identified a low Vp/Vs region ( 1.5), with a minimum ratio of 1.44 accompanied $\mathrm{v}_{j}$ low $\mathrm{Vp}$ (anomaly 3 ). Low $\mathrm{Vp} / \mathrm{Vs}$ ratio of about 1.5 and low Vp could be characteristin o r ver-pressured gas-filled rocks (Koulakov et al 2020; Kuznetsov et al. 2017). Indeed, at the Campi Flegrei volcano (De Siena et al., 2010; Chiarabba and Moretti, 2006), a $\mathrm{V}_{\mathrm{p}} \boldsymbol{V}_{\mathrm{s}}$ ratio lower than 1.5 and low $\mathrm{Vp}$ were linked to observed degassing at the surface a $^{\urcorner} \mathrm{a}$ interpreted as gas-saturated rock. Similar observations have been made at Yellowstone caldera (e.g. Husen et al., 2004), Naruko volcano (Nakajima and Hasegawa, 2003), Mount Spurr (Koulakov et al., 2013) and the Nevado del Ruiz volcano (Vargas et al., 2017). According to Kuznetsov et al. (2017), if a porous medium is saturated by dry gas, it will act like a sponge and will have a low compression modulus. This would lead to very low $\mathrm{Vp}$, which is exactly what we observed under the HS structure (figures 8,9 ). We cannot exclude the possibility of sea water infiltration that may reduce the $\mathrm{Vp} / \mathrm{Vs}$ ratio (Koulakov et al., 2020). However, because of no Vs variation in the model and because of its location above 10 
$\mathrm{km}$ depth, even if this anomaly is recovered by synthetic test, we cannot exclude the existence of an artifact. Moreover, station corrections may have an influence. The coincidence of anomaly 3 and the degassing HS should be investigated in future studies to understand the role and the effect of each parameter: potential gas saturated rock existing below the HS and/or sea water infiltrations.

\subsection{Role of the inheritance}

As indicated at the beginning of this section, we consider hat everything higher than the local $\mathrm{Vp} / \mathrm{Vs}$ average is an anomaly (>1.66). Using a $\mathrm{V}_{\mathrm{p} /} \mathrm{s}^{\mathrm{s}}$ ratio isocontour equal to 1.69 and 1.71 on figures 8 and $9(\mathrm{~B}, \mathrm{C})$ respectively, we im $\mathrm{a}_{c}^{\mathrm{r}} \mathrm{ed}$ conduits with several branches linking the two reservoirs A and B and the hypothet ca. reservoir C. The corresponding $d V p$ and $\mathrm{dVs}$ are heterogeneous, with mainly low $\mathrm{d}$. nnd high or low $\mathrm{dVp}$. Some of the paths that trend toward the surface coincide $v_{r}$ th sathymetric volcanic mounts, such as HS (figure 8, FF', anomaly 6) but are weak and fur 'her study is needed. In addition, some of the branches at $25 \mathrm{~km}$ depth are aligned in a NIV- $\mathrm{F}$ direction (along the $\mathrm{N} 130^{\circ}$ ridge, figure 7) and with sea bottom eruption sites (figl: e 1). These paths could reflect cracks in accordance with the immature right-lateral wrenc:irg of the lithosphere (Feuillet et al., 2021) or old crystallized conduits. We could als cunsider a combined hypothesis of an old fracture zone where few fractures may be used by previous magmatic fluids that are now crystallized like in the N130 volcanic ridge. This is our preferred interpretation. Indeed, Feuillet et al. (2021) noted that the $\mathrm{N} 130^{\circ}$ volcanic ridge offshore, East of Mayotte has the same orientation as other volcanic features located northeast of Mayotte and around the Comoros islands. These features - dykes, vent alignments, and rift zones - are arranged in a left-lateral en-echelon structure similar to extensional tectonic structures undergoing oblique extension. In this configuration, Feuillet et al. (2021) inferred that the $\mathrm{N} 130^{\circ}$ Mayotte volcanic ridge results from volcanism and tectonic 
influences. This extensional structure results from a wide E-W striking zone that transfers strain between the East African rift and the Madagascar grabens (Feuillet et al., 2021). Such a structure may induce high-permeability fracture zones that can be used for magma storage, i.e. magmatic reservoirs. These fracture zones are likely imaged as the $\mathrm{N} 130^{\circ}$ low $\mathrm{Vs}$ and $\mathrm{Vp} / \mathrm{Vs}$ anomaly at $25 \mathrm{~km}$ depth in our 3D model. Considering the 3 potential reservoirs we have also imaged, these fractures may be used for magma transport and could now be crystallized (green to brown shaded structure in figure 9). Such old conduits have been imaged at the Atka volcanic complex (Koulakov et al., 2020) and Gorely vol ?no in Kamtchatka (Kuznetsov et al. 2017). We note that some of the conduits rentified stem eastward, in the NVE direction (segment ABC, figure 8). However, we a not have the resolution below the NVE to clearly image this connection.

\section{Conclusion}

We calculated the first 3D velo: ${ }^{\mathrm{t}} \mathrm{y}$ models offshore East Mayotte $\left(110 \times 90 \times 70 \mathrm{~km}^{3}\right)$ using earthquakes recorded betwean Ff oruary and November 2019, resulting from the seismo-volcanic crisis that struck : Tayoite since May 2018. We used 3,699 events with 45,359 P and 39,667 S phases, recora t ' n 70 onshore and offshore stations. The passive tomography used for this study high ${ }^{\prime} \mathrm{g}_{\mathrm{I}}$ s for the first time the old East Mayotte plumbing system, deeply entrenched into the mantle, whose heart seems to be located below the HS area. The results also indicate magmatic materials and fractures induced an overall decrease of $\mathrm{P}$ and $\mathrm{S}$ velocity in the crust and the mantle.

Considering reservoirs $\mathrm{A}$ and $\mathrm{B}$, low $\mathrm{Vs}$ and high $\mathrm{Vp} / \mathrm{Vs}$ areas may be interpreted as magma reservoirs more or less consolidated/old (anomalies 1, 2 respectively), with the presence of melt, mush, and/or fluids. The variations in the Vp model related to reservoirs $\mathrm{A}$ and B may be associated with the amount of fluid saturation, crack density, thermal properties, 
and lithology (Lees, 2007). Indeed, the percentage of melt may explain the difference between A and B. Vp variation could also be due to differences in the nature of the magma product, where reservoir B may present partial melt and mush of a more evolved phonolitic magma (Berthod et al., in press). Reservoir B could also be the source of volcanism below the HS. On the other hand, reservoir A may be a more primitive magma, directly feeding the NVE. The reservoirs are connected by several fractures and/or old crystallized conduits, whose existence could have been influenced by the regional strain. The overall spatial distribution of the volcanic plumbing system, and mainly the structures aligning in a $\mathrm{N}_{2} 29^{\circ}$ direction parallel to sea bottom volcanic materials, seems to be clearly controlled ${ }^{1} y_{t}$ re-existing fracture zones deep-

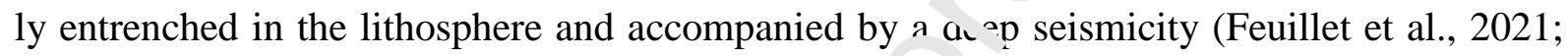
Berthod et al., 2021; Lemoine et al., 2020; Cesca ft a', 2020; Tzevahirtzian et al., 2021). These pre-existing fracture zones may be infl $e_{\mathrm{e}} \cdot \mathrm{er}^{\mathrm{r}}$. by the immature right-lateral wrenching of the lithosphere between the Lwandle nd Somalian plates proposed by Famin et al. (2020) and Feuillet et al. (2021). At the end, n- ore investigation should be conducted, such as active tomography, to understand more rea. $^{1} \mathrm{v}$ the first kilometers of the crust and to determine the existence, or not, of anomaly 2,5 ( $\mathrm{nypothetical}$ reservoir $\mathrm{C}$ ) and 6 . We note that we were not able to clearly image the $\mathrm{N} F \mathrm{~F}$ onnections to other reservoirs or conduits due to lack of resolution in that part of the tuuy area. We observe here a connection between the mantle and the crust that feeds the system, similar to what has been observed at Toba volcano (e.g. Masturyono et al., 2001).

Our study gives a physical/structural image of the volcanic plumbing. It provides a context for other disciplines and future studies, and acts as a baseline for the current state of the system. There are several additional studies that are needed to improve our understanding of this volcanic plumbing system. For instance, an attenuation model should be investigated as it is sensitive to rock temperature and can change by several orders of magnitude if there is 
a presence of melt (e.g. Lees 2007). Moreover, local active tomography can provided a clearer assessment of what kind of material and how much is present under the NVE, as well as below the HS, where degassing is occurring closer to Petite Terre, and where past volcanic eruptions have been identified (Feuillet et al., 2021).

\section{Authors contributions}

Océane Foix: Conceptualization, Methodology, Software, Validation, Data Curation, Writing - Original Draft, Writing - Review \& Editing and Visualization C: - sstity Aiken: Conceptualization, Software, Writing - Review \& Editing, Supervisi un ?nd Funding Acquisition (postdoctoral position). - Jean-Marie Saurel: Resources, Snıvare, Writing - Review \& Editing. MAYOBS/REVOSIMA Seismology Group: Rescarı `s, the group manually picked more than 4,000 earthquakes and cleaned the data L se . Nathalie Feuillet, Stephan J. Jorry, Emmanuel Rinnert and Isabelle Thinc $?$ : r.esources (as PIs of the MAYOBS oceanographic cruises), Writing - Review \& Editing - nd Funding Acquisition (which notably allowed the OBS data acquisitions).

\section{Acknowledgements}

We would like to expre s vur gratitude to all people who contributed to the acquisition of this spectacular data set. Instrument deployment and research oceanographic MAYOBS cruises and Tellus Mayotte project has been funded by the CNRS (National Scientific Research Agency), MI (Interior Ministry), MOM (Overseas Territory Ministry) and MTE (Environment Ministry), MESRI (Higher Education, Research and Innovation Ministry) MINARM (Armed Forced Ministry). MAYOBS oceanographic campaigns were conducted with the help and collaborations of French research institutions: Institut de Physique du Globe de Paris (IPGP), BRGM-French geological survey, and Institut Français de Recherche pour l'Exploitation de la 
Mer (IFREMER). We thank the help and collaboration of the Genavir technicians and engineers. We want to thank the crew of R/V Marion Dufresne (TAAF/IFREMER/LDA) and their Captains A.Eyssautier and F.Landreau. Since the beginning of the crisis, several seismic stations have been deployed by several person that we would like to thanks here: Didier Bertil, Alison Colombain, Maxime Bès de Berc, Marc Grunberg, Christophe Sira, Antoine Schlupp, Jérôme van der Woerd, Céleste Broucke, Hélène Jund, Grégoire Dectot, Aline Peltier and Philippe Kowalski. For the OBS deployment, we thank Romuald Daniel, Simon Besançon, Wayne Crawford and Jérémy Gomez and Pascal Pelleau, Pjorre Guyavarch, Mickaël Roudault, Emmanuel Maros and Pascal Pelleau. We also wo ^lс ' 1 ke to say our gratitude to the REseau VOlcanologique et SIsmologique de MAyotte (REVOSIMA) for the multiple exchanges and to IFREMER scientific direction for finu.ng the postdoctoral position. The figures of the paper were produced using Gene ic M.pping Tool (Wessel et al., 2013), Adobe Illustrator, Surfer 11 and Voxler Golder. Sc twares, as well as Python, Matlab and Microsoft Excel. We are grateful to the reviewers '

Supplementary data

Supplementary material

\section{References}

Audru J. C., Guennoc P., Thinon I., and Abellard O., (2006). Bathymay : la structure sous-marine de Mayotte révélée par l’imagerie multifaisceaux. Comptes Rendus - Geoscience, 338(16), 1240-1249. https://doi.org/10.1016/j.crte.2006.07.010

Barruol G., Sigloch K., Scholz J.-R., Mazzullo A., Stutzmann E., Montagner J.-P., Kiselev S., Fontaine F. R., Michon L., Deplus C., Dyment, J. (2019). Large-scale flow of Indian Ocean asthenosphere driven by Réunion plume. Nat. Geo., 12, 1043-1049. https://doi.org/10.1038/s41561-019-0479-3

Bazin S., Feuillet N., Duclos C., Crawford W., Nercessian A., Bengoubou-Valérius M., Beauducel F., Singh S.C., (2010). The 2004-2005 Les Saintes (French West Indies) seismic aftershock sequence observed 
with ocean bottom seismometers. Tectonophysics, 498, 91-103

Berthod C., Médard E., Bachèlery P., Gurioli L., Di Muro A., Peltier A., Komorowski J.C., Benbakkar M., Devidal J.-L., Langlade J., Besson P., Boudon G., Rose-Koga E., Deplus C., Le Friant A., Bickert M., Nowak S., Thinon I., Burckel P., Hidalgo S., Kaliwoda M., Jorry S.J., Fouquet Y., Feuillet N., (2021). The 2018-ongoing Mayotte submarine eruption: 1 magma migration imaged by petrological monitoring. Earth and Planetary Science Letters, 571. https://doi.org/10.1016/j.epsl.2021.117085

Berthod C., Médard E., Di Muro A., Hassen Ali T., Gurioli L., Bachèlery P., Komorowski J.-C., Laporte D., Peltier A., Benbakkar M., Devidal J.-L., Langlade J., Besson P., Rose-Koga E., Deplus C., Le Friant A., Bickert M., Nowak S., Thinon I., Burckel P., Hidalgo S., Feuillet N Iorry S.J., Fouquet Y., (in press). Mantle xenolith-bearing phonolites feeding the active volcanic ri tge o Mayotte (Comoros archipelago, Mozambique Channel). Contribution to Mineralogy and Petr logy https://doi.org/10.1007/s00410-02101833-1

Bertil D., Roullé A, Lemoine A, Colombain A, Maisonhaute E snu ıectot G, (2018). MAYEQSwarm2018 : BRGM earthquake catalogue for the Earthquake ir ar n located East of Mayotte, May 10th -November 12th, 2018. https://doi.org/10.18144/372

Cesca S., Letort J., Razafindrakoto H.N.T., Heimanı `., Rivalta E., Isken M.P., Nikkhoo M., Passarelli L., and Petersen G.M., (2020). Drainage of - $\operatorname{det}_{\mathbf{1}}$ magma reservoir near Mayotte inferred from seismicity and deformation. Nat. Geo. 13(Janv ^. '). ...ps://doi.org/10.1038/s41561-019-0505-5

Chiarabba, C. and Moretti, M. (2006) An s.sight into the unrest phenomena at the Campi Flegrei caldera from Vp and Vp/Vs tomogra, 'hy. 1 ;rra Nova, 18: 373-379. https://doi.org/10.1111/j.1365-

\section{$\underline{3121.2006 .0070^{1}} \times$}

Chouet B., (1985). Excitation c : a buried magmatic pipe: a seismic source model for volcanic tremor. J. Geophys. Res. 90, 1881-1893. https://doi.org/10.1029/JB090iB02p01881

Darnet M., Wawrzyniak P., Tarits P., Hautot S., and D'Eu J. F., (2020). Mapping the geometry of volcanic systems with magnetotelluric soundings: Results from a land and marine magnetotelluric survey performed during the 2018-2019 Mayotte seismovolcanic crisis. Journal of Volcanology and Geothermal Research, 406, 107046.

Debeuf D., (2004). Etude de l'évolution volcano-structurale et magmatique de Mayotte, Archipel des Comores, océan Indien: approches structurales, pétrographique, géochimique et géochronologique, $\mathrm{PhD}$, La Réunion University, 277p 
De Natale G., Troise C., Trigila R., Dolfi D., Chiarabba C., (2004). Seismicity and 3D substructure at SommaVesuvius volcano: evidence for magma quenching. Earth Planet. Sci. Lett., 221, 181-196, https://doi.org/10.1016/S0012-821X(04)00093-7

De Siena L., Del Pezzo E., Bianco F., (2010). Seismic attenuation imaging of Campi Flegrei: Evidence of gas reservoirs, hydrothermal basins, and feeding systems. J. Geophys. Res. Solid Earth, 115(B9). https://doi.org/10.1029/2009JB006938

Deville E., Marsset T., Courgeon S., Jatiault R., Ponte J.P., Thereau E., Jouet G., Jorry S. J., Droz L., (2018). Active fault system across the oceanic lithosphere of the Mozambique Channel: Implications for the Nubia-Somalia southern plate boundary. Earth Planet. Sci. Lett., 5七-210-220. https://doi.org/10.1016/j.epsl.2018.08.052

Dobretsov N.L., Koulakov I.Y., and Litasov, Y.D., (2012). Migration . aths of magma and fluids and lava compositions in Kamchatka. Russian Geology and Geophys: _. 5. (12), 1253-1275. https://doi.org/10.1016/j.rgg.2012.10.001

Dofal A., Fontaine F.R., Michon L., Barruol G., and Tkal is H. (2018). Crustal structure variation across the southwestern Indian Ocean from receive' $\mathrm{ru}_{\mathbf{1}}$ stic $\mathrm{s}$ determined at Ocean-Bottom Seismometers. AGU Fall Meeting, Abstract ID T43G0497B

Edgar C.J., Wolff J.A., Olin P.H., Nichols H ${ }^{\top} \quad$ P.. 'ari A., Cas R.A.F., Reiners P.W., Spell T.L., Martí J., (2007). The late Quaternary Diego Her $\ldots$ - de . ¿ ormation, Tenerife: volcanology of a complex cycle of voluminous explosive phonolitic e". ptioı.s. J. Volcanol. Geotherm. Res. 160, 59-85. https://doi.org/10.1016/; 'volg - ores.2006.06.001

Emerick C.M., and Dunc $\urcorner$ R A., ( 982). Age progressive volcanism in the Comores Archipelago, eastern Indian Ocean and implicat ons for Somali plate tectonics. Earth Planet. Sci. Lett. 60(3), 415-428. https://doi.org/10.1016/0012-821X(82)90077-2

Famin V., Michon L. and Bourhane A., (2020). The Comoros archipelago: a right-lateral transform boundary between the Somalia and Lwandle plates. Tectonophysics 789-228539. https://doi.org/10.1016/j.tecto.2020.228539

Feuillet N., Nostro C., Chiarabba C., Cocco M, (2004). Coupling between earthquake swarms and volcanic unrest at the Alban Hills Volcano (central Italy) modeled through elastic stress transfer. Journal of Geophysical Research Vol. 109, B02308. https://doi.org/10.1029/2003JB002419

Feuillet N., Jorry S.J., Rinnert E., Thinon I., Fouquet Y., (2019). MAYOBS. https://doi.org/10.18142/291 
Feuillet N., Jorry S.J., Crawford W.C., Deplus C., Thinon I., Jacques E., Saurel J.-M., Lemoine A., Paquet F., Daniel R., Gaillot A., Satriano C., Peltier A., Aiken C., Foix O., Kowalski P., Laurent A., Beauducel F., Grandin R., Ballu V., Bernard P., Donval J.-P., Géli L., Gomez J., Pelleau P., Guyader V., Rinnert E., Besançon S., Bertil D., Lemarchand A., Vanderwoerd J., (2021). Birth of a large volcanic edifice through lithosphere-scale dyking offshore Mayotte (Indian Ocean). Nature Geoscience. https://doi.org/10.1038/s41561-021-00809-x

Hamada, (2004). Reservoir Fluids Identification Using Vp/Vs Ratio. Oil \& Gas Science and Technology - Rev. IFP, Vol. 59, No. 6, pp. 649-654. https://doi.org/10.2516/ogst:2004046

Husen S., Smith R.B., Waite G.P., (2004). Evidence for gas and magmatic sc rces beneath the Yellowstone volcanic field from seismic tomographic imaging. J. Volcanol. Geot ıerm. Res., 131, 397-410. https://doi.org/10.1016/S0377-0273(03)00416-5

Jacques E., Feuillet N., Aiken C., Lemoine A., Crawford W.C., $\Gamma_{-1}^{-1}$ us $_{\text {S., }}$ Thinon I., Saurel J-M., Bès de Berc M., Broucke C., Colombain A., Daniel R., Dectot G., Poı. A., Foix O., Gomez J., Grunberg M., Kowalski P., Laurent A., Léger F., Lemarchand A., ai d ‘’e 'eau P., (2019). The 2018-2019 Mayotte Seismic Crisis: Evidence of an upper Mantle Rift' „g ?.veı.' ? AGU Fall Meeting, V43I-0221

Kennett B., Engdahi E., and Buland R., (1995). Cons. "aints on seismic velocities in the earth from travel times. Geophys. J. Int 122, 108-124. https." ${ }^{\prime \prime}$ dol. $\cdot$ rg/10.1111/j.1365-246X.1995.tb03540.x

Koulakov I., and Sobolev S. V., (2006). Hindukush region. Geophys I. Inı., 164(2), 425-440. https://doi.org/10.1111/j.1365$\underline{246 X .2005 .02841 . X}$

Koulakov I., (2009). LOTOS Tode for Local Earthquake Tomographic Inversion: Benchmarks for Testing Tomographic Algorith ns. Bulletin of the Seismological Society of America, 99(1), 194-214. https://doi.org/10.1785/0120080013

Koulakov I., Yudistira T., Luehr B.G., and Wandono X., (2009a), P, S velocity and VP/VS ratio beneath the Toba caldera complex (northern Sumatra) from local earthquake tomography, Geophys. J. Int., 177, 1121-1139. https://doi.org/10.1111/j.1365-246X.2009.04114.X

Koulakov I., West M., Izbekov P., (2013). Fluid ascent during the 2004-2005 unrest at Mt. Spurr inferred from seismic tomography. Geophys. Res. Lett., 40, 4579-4582. https://doi.org/10.1002/grl.50674

Koulakov I., Boychenko E., and Smirnov S. Z., (2020). Magma Chambers and Meteoric Fluid Flows Beneath the Atka Volcanic Complex (Aleutian Islands) Inferred from Local Earthquake Tomography. Geosci- 
ences 10, 214. https://doi.org10.3390/geosciences10060214

Koulakov I., Shapiro N.M., Sens-Schönfelder C., Luehr B.G., Gordeev E.I., Jakovlev A., Abkadyrov I., Chebrov D.V., Bushenkova N., Droznina S.Y., Senyukov S.L., Novgorodova A., and Stupina T., (2020a). Mantle and crustal sources of magmatic activity of Klyuchevskoy and surrounding volcanoes in Kamchatka inferred from earthquake tomography. Journal of Geophysical Research: SolidEarth. https://doi.org/10.1029/2020JB020097

Kumagai H., Miyakawa K., Negishi H., Inoue H., Obara K., Suetsugu D., (2003). Magmatic dyke resonances inferred from very-long-period seismic signals. Science 299, 2058-2061. https://doi.org/10.1126/science.1081195

Kuznetsov P., Koulakov I., Jakovlev A., Abkadyrov I., Deev E., Gordeev Z., Sı nyukov S., El Khrepy S., Al Arifi N., (2017). Structure of Volatile Conduits Beneath Gorely Iolcc no (Kamchatka) Revealed by Local

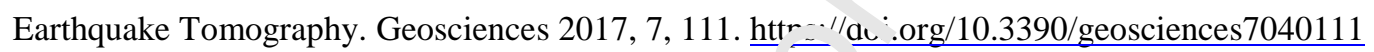

Lavayssière A., Crawford W., Saurel J.M., Satriano C., Komorcrvs. J.-C., MAYOBS/REVOSIMA Seismology Group, (2020). New 1D velocity model and absc $u^{+} \geq 1$ cations image of Mayotte seismo-volcanic region. AGU Fall Meeting - V019-724062

Laurent A., Satriano C., and Bernard P., (2020). Deı `tion, location and characterization of VLF events during the 2018-2019 seismovolcanic crisj i in N-yotte. HAL Archive Ouvertes. https://hal.archivesouvertes.fr/hal-02446050

Lees J.M., and Crosson R.S., (1989). Comø zraphic inversion for three-dimensional velocity structure at Mount St. Helens using earthqu ’ke d ıа. J. Geophys. Res., 94(B5), 5716-5728.

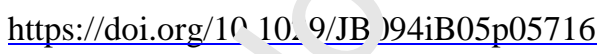

Lees J.M., (2007). Seismic tom sgraphy of magmatic systems. J. Volcanol. Geotherm. Res., 167, 37-56. https://doi.org10.1016/j.jvolgeores.2007.06.008

Lemoine A., Briole P., Bertil D., Roullé A., Foumelis M., Thinon, I., Raucoules D., de Michele M., Valty P., and Hoste Colomer R., (2020). The 2018-2019 seismo-volcanic crisis east of Mayotte , Comoros islands : seismicity and ground deformation markers of an exceptional submarine eruption. Geophys. J. Int. 223, 22-44. https://doi.org/10.1093/gii/ggaa273

Lin G., Shearer P.M., Matoza, Okubo P.G., and Amelung F., (2013). Three-dimensional seismic velocity structure of Mauna Loa and Kilauea volcanoes in Hawaii from local seismic tomography. J. Geophys. Res. Solid Earth, 119, 4377-4392. https://doi.org/10.1002/2013JB010820 
Masson F., Sira C., Schlupp A., Bontemps M., Regis E., Bertil D., Lemoine A., Roll A., Tronel F., van der Woerd J., (2018). Note macrosismique préliminaire du BCSF-RENASS. http://www.franceseisme.fr/donnees/Note_macro-BCSF-RENASS-Mayotte-13-07-2018.pdf Masturyono, McCaffrey R., Wark D.A., Roecker S.W., Fauzi G., Sukhyar I., (2001). Distribution of magma beneath Toba Caldera, North Sumatra, Indonesia, constrained by 3Dimensional P-wave velocities, seismicity, and gravity data. Geochem. Geophys. Geosyst. 2 (4). https://doi.org/10.1029/2000GC000096

Michon, L., (2016). The Volcanism of the Comoros Archipelago Integrated at a Regional Scale. In : Active Volcanoes of the Southwest Indian Ocean, Active Volcanoes of the World. P. Bachelery et al (Eds.).

Nakajima J., Matsuzawa T., Hasegawa A., Zhao D., (2001). Three-dimensio, 1 structure of Vp, Vs, and Vp/Vs beneath northeastern Japan: Implications for arc magmatism and fuid: J. Geophys. Res., 106( B10), 21843- 21857. https://doi.org/10.1029/2000JB000008

Nakajima J., Hasegawa A., (2003). Tomographic imaging of seis - v ' locity structure in and around the Onikobe volcanic area, northeastern Japan: Implications for $f^{\prime} \mathrm{ul}$. đistribution. J. Volcanol. Geotherm. Res.,

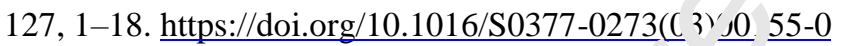

Nougier J., Cantagrel J.M., and Karche J.P., (198f, . . ' 'e L' 'mores archipelago in the western Indian Ocean: volcanology, geochronology and geodynamic s. tting, J. African Earth Sci., 5(2), 135-144. https://doi.org/10.1016/0899-5362(9<)9u (93-5

Oppenheimer C., Lomakina A.S., Kyle F.2 . 1_..tgsbury N.G., Boichu M., (2009). Pulsatory magma supply to a phonolite lava lake. Earth P'· net. ¿ci. Lett., 284, 392-398. https://doi.org/10.1016/j.eps1.2009.04.043

Paige C., Saunders M.A., (1982). ' SQ \: an algorithm for sparse linear equations and least squares problems. ACM Trans. Ma`h. $₫$ ft., , 43-71.

Phethean J.J.J., Kalnins L.M., r an Hunen J., Biffi P.G., Davies R.J., McCaffrey K.J.W., (2016). Madagascar's escape from Africa: A high-resolution plate reconstruction for the Western Somali Basin and implications for supercontinental dispersal. Geochemistry, Geophysics, Geosystems, 17(12), 5036-5055, https://doi.org/10.1002/2016GC006624.

Saurel J.-M., Jacques E., Aiken C., Lemoine A., Retailleau L., Lavayssière A., Foix O., Laurent A., Mercury N., Crawford W., Lemarchand A., Daniel R., Pelleau P., Bès de Berc M., Dectot G., Bertil D., Roulle A., Broucke C., Colombain A., Besançon S., Guyavarch P., Kowalski P., Roudaut M., Battaglia J., Bodihar S., Bouin M.P., Canjamale K., Desfete N., Dofal A., Doubre C., Dretzen R., Ferrazzini V., Fontaine F., Géli L., Griot C., Grunberg M., Guzel E.C., Hoste-Colomer R., Lambotte S., Léger F., Vergne J., 
Satriano C., Tronel F., Vanderwoerd J., Feuillet N., Fouquet Y., Jorry S.J., Rinnert E., and Thinon I., (resubmitted to Geophys. J. Int.). Mayotte seismic crisis: building knowledge in near real-time combining land and ocean-bottom seismometers, first results.

Stamps D.S., Kreemer C., Fernandes R., Rajaonarison T.A., and Rambolamanana G., (2020). Redefining East African Rift System kinematics. Geology, 49, 150-155. https://doi.org/10.1130/G47985.1

Talandier J., Hyvernaud O., Maury R. C., (2016). Unusual seismic activity in 2011 and 2013 at the submarine volcano Rocard, Society hot spot (French Polynesia). Geophys. Res. Let. 43(9). https://doi.org/10.1002/2016GL068342

Thinon I., Leroy S., Lemoine A.; (2020) SISMAORE cruise, RV Pourquoi p. : ?, https://doi.org/10.17600/18001331

Tzevahirtzian A., Zaragosi S., Bachèlery P., Biscara L., Marchès E., (. 021) Submarine morphology of the

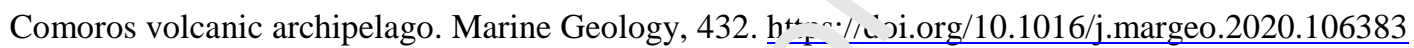

Vargas C.A., Koulakov I., Jaupart C., Gladkov V., Gomez E., E' K. repy S., Al-Arifi N., (2017). Breathing of the Nevado del Ruiz volcano reservoir, Colombia, ir $\mathrm{fe}_{\mathrm{r}}$ ' from repeated seismic tomography. Sci. Rep., 7 , 46094. https://doi.org/10.1038/srep4609'.

Wessel P., Smith W. H. F., Scharroo R., Luis J., Wo 'e F., (2013). Generic Mapping Tools: Improved Version Released. EOS Trans. AGU, 94(45', ?. 4`'9-410. https://doi.org/10.1002/2013EO450001

Zelt C. A., and Barton P. J., (1998). Thr _ Jit_. ssional seismic refraction tomography: A comparison of two methods applied to data fro־ the 'aeroe Basin. Journal of Geophysical Research: Solid Earth, 103(B4), 7187-7210. https://doi.c “ $\div / 10$ i029/97JB03536

Zinke J., Reijmer J.J.G., Thot assiı B.A., Dullo W.C., Grootes P.M., and Erlenkeuser H., (2003a). Postglacial flooding history of M; yotte lagoon (Comoro archipelago, southwest Indian Ocean). Marine Geology, 194(3-4), 181-196. https://doi.org/10.1016/S0025-3227(02)00705-3

Zinke J., Reijmer J.J.G., and Thomassin B.A., (2003b). Systems tracts sedimentology in the lagoon of Mayotte associated with the Holocene transgression. Sedimentary Geology, 160(1-3), 57-79. https://doi.org/10.1016/S0037-0738(02)00336-6 


\section{Declaration of interests}

The authors declare that they have no known competing financial interests or personal relationships that could have appeared to influence the work reported in this paper.

$\square$ The authors declare the following financial interests/personal relationships, which may be considered as potential competing interests:

Author statement: Océane Foix: Conceptualizatic،, inethodology, Software, Validation, Data Curation, Writing - Original Dr: ft, $\mathrm{A}^{\mathrm{N}}$. iting - Review \& Editing and Visualization. Chastity Aiken: Concepti ^-li_ation, Software, Writing - Review \& Editing, Supervision and Funding Acy' 'isition (post-doctoral position). Jean-Marie Saurel: Resources, Software, Writinç - Review \& Editing. MAYOBS/REVOSIMA Seismology Group: Resource` tri group manually picked more than 4,000 earthquakes and cleaned the $d_{c}{ }^{+} a k$ ased. Nathalie Feuillet, Stephan J. Jorry, Emmanuel Rinnert and Isar oll Thinon: Resources (as PIs of the MAYOBS oceanographic cruises), Writiny - Review \& Editing and Funding Acquisition (which notably allowed the OBS data acquisitions).

Highlights $(<85$ characters $) \cdot$ We calculated the first 3-D velocity models offshore Mayotte that revealed 3 potential magma reservoirs more or less related to the ongoing eruption. $\bullet$ Reservoirs are connected by several crystallized conduits with a spatial distribution constrained by regional strike-slip faulting of the lithosphere in the $\mathrm{N} 130^{\circ}$ directions. - A gas saturated area was identified below the Fer-à-Cheval structure, known for its presently 
degassing acoustic plumes. 